Željko Bošković

University of Connecticut ${ }^{*}$

\title{
WHAT IS SENT TO SPELL-OUT IS PHASES, NOT PHASAL COMPLEMENTS ${ }^{* *}$
}

\section{INTRODUCTION}

An appealing property of the phase theory, emphasized already in Chomsky (2000), is that phases are relevant to many phenomena. In fact, given the variety of the phenomena where phases have been argued to be relevant, we may expect all domain-based mechanisms to be stated in terms of phases, with phases defining their locality domain.

One of the mechanisms where phases are crucially assumed to be involved is multiple spell-out. The standard assumption in the Government and Binding framework as well as early minimalism was that there is a single point of spell-out, where the derivation separates into the phonology branch and the semantics branch. The advent of minimalism, where one of the guiding hypotheses is that UG is an optimal way of satisfying requirements imposed on the language faculty by the external systems that the language faculty interfaces with, led to the elimination of DS and SS, the "internal" levels of representation which do not interface with the external systems. While under Chomsky's (1993) single spell-out approach PF and LF considerations determine when spell-out applies, ${ }^{1}$ the assumption that spell-out applies only once, which was adopted in that work, still hid a trace of SS. A number of authors (see especially Uriagereka 1999; Epstein 1999; Epstein et al 1998; and Chomsky 2000, 2001) have argued that Spell-Out may apply multiple times, which has led to a radically derivational nature of the computation, with the interfaces accessing syntactic computation as the derivation proceeds without the mediation of PF and LF levels of representation.

A question that arises under the multiple spell-out approach is what determines spell-out units. The standard assumption is that phases do that. In the original proposal regarding phases (Chomsky 2000), what was sent to spell-out was the phase itself (see also Franks and Bošković 2001). The assumption was later modified in that what was sent to spell-out was assumed to be the complement of the phase head (referred to below as phasal complement for ease of exposition), which is in fact the standard

* zeljko.boskovic@uconn.edu

** The article is based upon work supported by the NSF under Grant BCS-0920888. For helpful suggestions, I thank Renato Lacerda, Adrian Stegovec, two anonymous reviewers, the participants of my Fall 2016 UConn seminar, and the audiences at SinFonIJA 8, Tsinghua University (Beijing), University of Sarajevo, and University of Pennsylvania.

1 Movement that takes place prior to spell-out was assumed to be driven by the need to eliminate strong features, which are illegitimate PF objects. Procrastinate, which favors LF movement, was assumed to delay movement that is not motivated by PF considerations until LF. 
assumption currently. ${ }^{2}$ This has, however, left us with a rather strange situation: while phases are the crucial units in the multiple spell-out framework, for all practical purposes the crucial units are actually not phases but phasal complements. But, in contrast to phases, phasal complements have no theoretical status. Witness e.g. the great deal of effort that has gone into coming up with a proper, unified definition of what counts as a phase; there has been nothing like that regarding phasal complements-no one has even tried to come up with a unified definition of phasal complements. The reason for that is quite obvious: phasal complements have no theoretical status in phase theory. But phasal complements should then play no role in spell-out; what is transferred to spell-out should be phases, not phasal complements. The goal of this article is to explore the viability of such an approach to spell-out, which will in fact be argued to be superior in several respects to the phasal complement spell-out approach. As we will see below, the real reason for the modification of the original approach in this respect, i.e. for adopting the assumption that what is sent to spell-out is the phasal complement, not the phase itself, is actually successive-cyclic movement, more precisely, the interaction of successive-cyclic movement and multiple spell-out. As a result, arguing for phasal spell-out will inevitably involve re-examining successive-cyclic movement. Most of the article will therefore be devoted to exploring the interaction of multiple spell-out and successive-cyclic movement.

I will start the discussion by noting in section 2 a rather straightforward argument for phasal spell-out regarding matrix clauses. In section 3 I show that Chomsky's (2013) labeling system also favors phasal spell-out. Section 4 presents several arguments for phasal spell-out regarding syntax-phonology interaction, in particular, cliticization in Bulgarian and Arabic, stress assignment in German, raddoppiamento fonosintattico in Abruzzese, and tone sandhi in Taiwanese. In section 5 I turn to the interaction of successive-cyclic movement and multiple spell-out. ${ }^{3}$ The adoption of phasal spell-out will lead us to an approach to successive-cyclic movement which is rather different from the one that is currently standardly assumed, the reason being that the latter looks the way it does because of the assumption that what is sent to spell-out is the phasal complement, not the phase itself. Since the analysis from section 5 has a number of consequences, the bulk of the article will be devoted to the issues discussed in that section (the main phenomena discussed in that section concern locality of movement and stress assignment), some of which go beyond the main goal of this article, which is to make a case for phasal spell-out, but are necessary since they are affected by the phasal spell-out analysis of successive-cyclic movement. Finally, section 6 concludes the article.

2 Chomsky (2000:131-132) suggests that phases are sent to spell-out. Chomsky (2001) is already somewhat ambivalent in this respect: thus, Chomsky (2001:12) suggests phasal spell-out, while Chomsky (2001:13) suggests phasal complement spell-out.

3 The discussion in that section is based on Bošković (2015b), putting the analysis from that work in a broader perspective (i.e. framing it within more general theoretical concerns), and also adding new arguments. 


\section{MATRIX CLAUSES}

In addition to the obvious conceptual argument which concerns the fact that phasal complements have no theoretical status in phase theory (only phases do), a rather straightforward argument for the original assumption that what is sent to spell-out is the phase itself concerns matrix clasuses. The phasal spell-out approach does not require special provisos regarding matrix clauses. They, however, significantly complicate the phasal complement spell-out approach. In particular, if only phasal complements are sent to spell-out, matrix clauses will never be sent to spell-out. Under this approach, we then need an additional assumption regarding matrix clauses to ensure that not just IP but also CP, which is a phase, not a phasal complement, is sent to spell-out in (1).

(1) $\left[_{\mathrm{CP}}\right.$ What did $[$ IP John buy $\left.]\right]$ ?

In other words, under the phasal complement spell-out approach we still need to assume that in certain cases (i.e. matrix clauses) what is sent to spell-out is a phase. This is not an innocent assumption given that in many languages, matrix and embedded clauses look exactly the same, which means that at the point where the clause itself is built we cannot tell whether we are dealing with an embedded or a matrix clause. This is e.g. the case with the embedded and the matrix clause in English (2a) and (2b) and the embedded and the matrix clause in English (3a) and (3b), though it is easy to come up with even more straightforward examples of this sort for many languages. ${ }^{4}$

(2) a) John left.

b) I think John left.

a) Who left?

b) I wonder who left.

The assumption that what is sent to spell-out is phasal complements thus requires an additional non-innocent proviso to handle matrix clauses, thus also requiring phasal spell-out in this case. On the other hand, the phasal spell-out approach is consistent in that only phases are ever sent to spell-out under this approach.

\section{LABELING AND PHASAL SPELL-OUT}

One of the issues that was taken for granted in the GB framework but has undergone close scrutiny within minimalism concerns labeling of the structure created in the syntax, i.e determining which element projects when two elements undergo merger. To take a concrete example, it was standardly assumed in early minimalism that when e.g. arrive and John are merged \{arrive, John\}, information needs to be provided that the resulting object is verbal in nature. In more technical terms, arrive projects, labeling the resulting object. In early minimalism labeling was taken to be part of the definition

4 See Agbayani (2000), An (2007), Boeckx (2003), Bošković (2016b), McCloskey (2000), Pesetsky and Torrego (2001), among others, for arguments that examples like (3a-b) involve movement of who to SpecCP. 
of Merge: when $\mathrm{X}$ and $\mathrm{Y}$ are merged, either $\mathrm{X}$ or $\mathrm{Y}$ projects, i.e. labels the resulting object. Collins (2002), however, questioned the need for labeling, arguing that labeling should be eliminated. Chomsky $(2013,2015)$ has recently proposed a system that is in between early Minimalism and Collins (2002) in this respect, where unlabeled objects are allowed during the derivation but not in the final representation. In particular, like Collins, Chomsky $(2013,2015)$ argues that labeling is not part of the definition of Merge, Merge being a set-formation operation that combines two objects without label projection. However, Chomsky keeps the traditional assumption that when $\mathrm{X}$ and $\mathrm{Y}$ are merged, the nature of the resulting object needs to be specified. In the case at hand, it still needs to be specified that the object formed by the merger of arrive and John is verbal in nature. Crucially, Chomsky argues that syntax itself does not require this information; the information is required by the interfaces so that syntactic objects can be intepreted. In other words, although there is nothing wrong with unlabeled objects in the syntax, such objects are uninterpretable. Chomsky then provides an algorithm that specifies labels which applies at the point of transfer to the interfaces, labeling being interface-driven.

Under Chomsky's interpretation-driven approach to labeling we would expect labeling to take place at the point of transfer to the interfaces for what is being transferred to the interfaces. Under Chomsky's approach to spell-out, this should be the phasal complement. This is, however, not what Chomsky assumes. Although Chomsky assumes that what is sent to spell-out is the phasal complement, he crucially assumes that the whole phase is labeled at this point, not just the phasal complement. There is a clear inconsistency here; if labeling is strictly interpretation/interface-driven, with syntax itself not requiring labeling, what should be labeled is what is sent to the interfaces. The issue is, however, resolved if what is sent to the interfaces is indeed the whole phase. It is then not surprising that what is labeled is the whole phase, not just the phasal complement. Chomsky's $(2013,2015)$ labeling system, where labeling is assumed to be interface-driven and what is being labeled is phases, thus also naturally leads to the assumption that full phases, not phasal complements, are sent to spell-out.

\section{ARGUMENTS FOR PHASAL SPELL-OUT FROM SYNTAX-PHONOLOGY INTERACTION}

In this section I will present several arguments for phasal spell-out regarding syntaxphonology interaction. ${ }^{5}$ The arguments come from cliticization in Bulgarian, Macedonian and Arabic, stress assignment in German, raddoppiamento fonosintattico in Abruzzese, and tone sandhi in Taiwanese.

Some of the original arguments for multiple spell-out were in fact based on the assumption that what is sent to spell-out is the phase itself. I will start the discussion by

5 A potentially interfering factor here is the possibility of prosodic factors influencing spell-out domains (which can be implemented through readjustments of the initial prosodic phrasing), an issue that cannot be addressed here; for a recent survey of the relevant literature see Cheng and Downing (2016). 
summarizing one such argument from Franks and Bošković (2001), which concerns cliticization in Bulgarian and Macedonian. ${ }^{6}$ (4) illustrates the basic cliticization pattern for these languages (clitics are in boldface).
(4)
a) Vera mi go dade včera Vera me.dat it.acc gave yesterday 'Vera gave me it yesterday.'
b) Vera mi go včera dade.
c) Mi go dade Vera včera.
d) Dade mi go Vera včera.

$\begin{array}{ll}\text { Bg: OK } & \text { Mac: OK } \\ & \\ \text { Bg: * } & \text { Mac: * } \\ \text { Bg: * } & \text { Mac: OK } \\ \text { Bg: OK } & \text { Mac: * }\end{array}$

While in Macedonian the clitics always precede the verb, in Bulgarian they precede the verb except when preceding the verb would leave them in sentence initial position; in that case they follow the verb. What is going on here is rather straightforward. Bulgarian clitics are enclitics, i.e. they must encliticize, while Macedonian clitics procliticize. The V-clitic order is a last-resort strategy employed in Bulgarian when the enclitic requirement otherwise cannot be satisfied.

Bošković (2001) proposes a copy-and-delete account of the effect in question, based on a proposal regarding pronunciation of lower copies made in Franks (1998), which was later argued for by many authors. In particular, the proposal is that, as in the case of deletion of copies applying in LF, with PF deletion of copies, there is no rigid requirement to always pronounce one particular copy: a lower copy of a non-trivial chain can be pronounced in PF iff this is necessary to avoid a PF violation (see Abels 2001; Bobaljik 2002; Bošković 2001, 2002a; Bošković and Nunes 2007; Franks 1998; Lambova 2002; Landau 2003; Pesetsky 1998; Reglero 2007; Stjepanović 2003, among others, for many cases of such lower copy pronounciation motivated by PF considerations.)
(5) a) X cl Vet
b) et $\mathrm{V} \mathrm{cl}$
c) $(\mathrm{X}) \mathrm{cl} \mathrm{Vet}$
(Mac)

In both Bulgarian and Macedonian the clitic undergoes movement, so that there is a copy of the clitic both preceeding and following the verb. In Macedonian, where clitics are proclitics, nothing goes wrong if the higher copy of clitic movement is pronounced, hence this copy must be pronounced, the lower copy being deleted in $(5 \mathrm{c})$. As a result, the cl-V order always obtains. When a phonologically realized element precedes a clitic in Bulgarian, as in (5a), the clitic can enclitize; since nothing goes wrong if the higher copy of the clitic is pronounced in (5a) this copy must be pronounced. However,

6 Another relevant work based on phasal spell-out is Fox and Pesetsky (2005). Since the Fox and Pesetsky argument is a bit more involved I refer the reader to the original work for discussion. It should, however, be noted that they do not share the assumption adopted in e.g. Chomsky (2000, 2001) and Uriagereka (1999), also adopted in this article, that the internal structure of what is sent to spell-out is inaccessible to the syntax. 
pronounciation of the higher copy would lead to a PF violation in (5b) since the enclitic requirement would not be satisfied. This is precisely the case where lower copy pronounciation is allowed, as in (5b). The analysis captures the above paradigm, including the last resort nature of the V-clitic order in Bulgarian, without positing any syntactic differences between clitics in Bulgarian and Macedonian, which is desirable given that syntactically, the clitics in this type of examples in Bulgarian and Macedonian behave in the same way in all respects.

Consider now (6), from Franks and Bošković (2001).

(6) a) $I$ ti go dade. and you.dat it.acc gave 'And (s)he gave it to you.'

b) *I dade ti go.

What these data indicate is that clitics can encliticize to the conjunction. As a result, we get the clitic-V order here, V-clitic order being disallowed.

Consider now the following paradigm from Franks and Bošković (2001).

(7) a) I ti go dade li?

and you.dat it.acc gave $\mathrm{Q}$

'And did (s)he give it to you?'

(Mac)

b) I dade li $\boldsymbol{t i} \quad \boldsymbol{g o}$ ?

and gave $\mathrm{Q}$ you.dat it.acc

'And did (s)he give it to you?'

c) *I ti go dade li?

d) *I ti go li dade?

e) *I li ti go dade?

'And did (s)he give it to you?'

The standard account of Bulgarian and Macedonian clitics is that they are adjoined to the verb (see e.g. Bošković 2001, 2002b; Franks and King 2000; note in this respect the ungrammaticality of (4b)). As a result, when the verb undergoes head-movement it carries the clitics with it, as illustrated by Macedonian (7a). The question particle $l i$ triggers $\mathrm{V}$-to-C movement in Macedonian and Bulgarian. V-movement carries the clitics along, hence the complex clitics $+\mathrm{V}$ precedes the complementizer $l i$ in $(7 \mathrm{a})$, which is the only possible word order here in Macedonian.

An unexpected word order, however, surfaces in Bulgarian. Recall the V-clitic order in Bulgarian is obtained through last-resort deletion of the highest clitic copy, when this is necessary to satisfy the enclitic requirement. Recall also that the conjunction can satisfy it, as shown by (6). One would then expect (7a) to be acceptable in Bulgarian too, given that the word order difference between the two languages noted above (regarding the $\mathrm{V}$-clitic order) arises only when there is nothing else in front of the clitics in Bulgarian. However, the word order of (7a) is unacceptable in Bulgarian, as (7c) 
shows. Instead, what we get is (7b), all other orders being unacceptable (7d-e). This is rather surprising. Why is it that lower copy pronunciation applies in (7b), although it does not in (6a)? Franks and Bošković (2001) provide a multiple spell-out account of these data, which is however crucially based on the original assumption that what is sent to spell-out is the phase itself.

Following Chomsky (2000), Franks and Bošković (2001) assume that CPs, but not IPs, are phases. Given that phases, not phasal complements, are sent to spell-out, this means that CPs, but not IPs, are sent to the phonology. Franks and Bošković also argue that the conjunct following $i$ is a $\mathrm{CP}$ in (7), since it is headed by $l i$, a $\mathrm{C}$ element. However, it is a bare IP in (6). Given that the conjunct in (6) is an IP, it will not be sent to the phonology until the whole structure is built. ${ }^{7}$ Since clitics can encliticize to $i$ all elements can then be pronounced in the highest position in (6).

On the other hand, in the $l i$ construction spell-out applies as soon as the conjunct following $i$, which is a $\mathrm{CP}$ hence a phase, is built. To avoid having a stranded enclitic in $\mathrm{PF}, t i$ go are pronounced in a lower position.

(8) $\left[_{\mathrm{CP}}\left[{ }_{\mathrm{C}}\right.\right.$ ti go dade+li] ti go dade $]$

The conjunction $i$ is only then added and we derive (7b):

(9) $\mathrm{i}\left[{ }_{\mathrm{CP}}[\mathrm{C}\right.$ igo dade + li $]$ ti go tade $]$

As for Macedonian, since its pronominal clitics can be proclitics, higher copies can be pronounced even without $i$.

(10) a) $\left[{ }_{\mathrm{CP}}[\right.$ [ti go dade] li] migo dade $]$

b) i $\left[{ }_{\mathrm{CP}}[\right.$ [ti go dade $]$ li $]$ mi go dade $]$

The paradigm in question provides an argument for multiple spell-out. The issue here is that the conjunction in Bulgarian (7) behaves as if it were not there (in contrast to (6)). The best and the most straightforward way of capturing this kind of situation where an element behaves as if it were not there is that it is indeed not there. Under multiple spell-out, the conjunction is actually not there at the relevant point of the derivation, which straightforwardly captures its invisibility. Notice, however, that the crucial component of the analysis is that what is sent to spell-out is the phase itself, not its complement. If phasal complements were to be sent to spell-out, what would be sent to spellout in (7) would be the IP, which means that the clitics-verb complex, which precedes the complementizer, would not be sent to spell-out before the conjunction is merged into the structure, incorrectly predicting (7c) to be acceptable and (7b) to be unacceptable, on a par with (6). The analysis thus provides an argument for phasal spell-out.

7 The implicit assumption here is that ConjPs are phases. (In fact, with an additional assumption (namely, that merger with a projection of $\mathrm{Conj}^{0}$ also triggers spell-out), the locality system from section 5 can be extended to the Coordinate Structure Constraint if ConjP is a phase.) 
There are other PF phenomena which also indicate that there is a spell-out boundary at the phasal edge. Consider stress assignment in all-new neutral sentences in German. The phenomenon has been discussed extensively in the literature. It would be way beyond the scope of this article to discuss it in any detail here. I will focus on a couple of constructions, which will be analyzed within the overall approach to phase-based pitch accent assignment from Kratzer and Selkirk (2007), where pitch accent assignment proceeds cyclically, with phases (i.e. spell-out) determining its domain. ${ }^{8}$ The relevant assumptions from Kratzer and Selkirk (2007) are given below (slightly modified):

(11) The spell-out domain is the prosodic domain for phrase stress.

(12) Phrase stress is assigned within the highest phrase within the spell-out domain.

(13) The Elsewhere Condition on Prosodic Spell-out: Phrase stress must be assigned within a spell-out domain with eligible material.

Consider in this respect (14), assuming an all-new neutral context. Kratzer and Selkirk argue that the bracketed element corresponds to a spell-out domain. What is important to note here is that the highest phrase within the domain receives phrase stress (eine Géige).

$$
\begin{aligned}
& \text { (14) ... dass ein Júnge [eine Géige an einen Freund schickte]. } \\
& \text { that a boy a violin to a.acc friend sent } \\
& \text { '...that a boy sent a violin to a friend.' } \\
& \text { (Kratzer and Selkirk 2007:107) }
\end{aligned}
$$

The question to address now is whether the spell-out domain corresponds to a full phase or a phasal complement. There is reason to believe that it is the former. Consider (15), where both the subject and the object of the embedded clause receive phrase stress.

(15) Ich glaube, dass María die Gesétze studiert.

I think that Maria the laws is.studying 'I think that Maria is studying the laws.' $\quad$ (Kratzer and Selkirk 2007:94)

The line of research going back to Kayne (1994) and Zwart (1993) argues that the OV order of languages like German results from object shift, i.e. movement to SpecvP. Even independently of this line of research, Diesing (1996) argues that non-contrastive definite objects must undergo movement in German. In other words, the object in (15) is generally assumed to undergo object shift/scrambling.

Given antilocality (the ban on movement that is too short), which bans movement within a phrase (see Bošković 1994, 2013a; Saito and Murasugi 1999; Abels 2003; Grohmann 2003, among many others), the movement in question can target SpecvP or a higher position, i.e. SpecvP is the lowest potential landing site for this movement.

8 I will, however, depart from Kratzer and Selkirk in some aspects of the syntax of the relevant constructions (see also Kahnemuyipour 2003 for an early version of (12)). 
Now, for the object to be stressed it cannot be located in the same spell-out domain as the subject. If the object moves to SpecvP, and what is sent to spell-out is the whole vP phase, the object and the subject will be in different spell-out domains, so that each element will receive stress. On the other hand, if what is sent to spell-out is the phasal complement, which is VP, the object and the subject would end up in the same spell-out domain, which means the object could not be stressed. The phasal spell-out system thus captures the stress pattern in (14), where both the subject and the object bear phrase stress, which is problematic for the phasal complement spell-out system.

Consider now the contrast between (16) and (17).

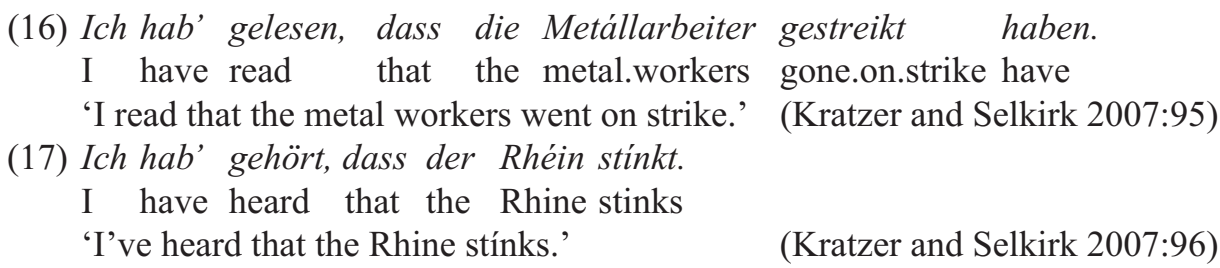

(16) involves a stage level predicate, and (17) an individual level predicate. Diesing (1992) argues that the subject in (16) can be located either in SpecvP or SpecTP in overt syntax, while the subject in (17) must be located in SpecTP. Assume this to be the case. ${ }^{9}$ What is important here is that the verb can be unstressed only in (16). Consider how these data can be handled under phasal spell-out. For (16), a derivation is available where the subject and the verb are in the same spell-out domain, the subject staying in SpecvP. On this derivation, the subject receives phrase stress as the highest phrase within the vP spell-out domain, which corresponds to the whole vP phase. This is not an option in (17), where the subject cannot be in SpecvP. Since the subject is located outside of $\mathrm{vP}$ in (17), the verb, which I assume is located in $\mathrm{v}$, is the only element within the vP phase, which is sent to spell-out, hence it receives stress under (13). ((13) assigns stress to the verb, which is a head, not a phrase, when there is nothing else in the spell-out domain that can receive stress. ${ }^{10}$ Not stressing the verb is thus not an option for (17) under phasal spell-out. This is, however, not the case under phasal complement spell-out. Without adopting any additional assumptions, the verb, located in v, should not get stress in (17) since it belongs to the same spell-out domain as the subject in

9 It should be noted that the issue in question is not settled. Assuming split IP, where IP splits into more than one phrase, makes the issue in question even trickier. What is needed for the argument given below to go through under such clausal structure is merely that subjects of individual level predicates cannot be located in the $\theta$-position in overt syntax (in fact, simply assuming that subjects of stage level predicates can be lower than subjects of individual level predicates may be enough; see in this respect the discussion of was-für split and the split-topic construction in Diesing 1992).

10 Since the subject of stage-level predicates can move outside of vP we would expect that the verb in examples like (16) can be optionally stressed. According to Kratzer and Selkirk (2007), this is indeed the case. 
spite of the subject being located outside of $\mathrm{vP}$, given that what is sent to spell-out is VP. The no stress on the verb should in fact be the only option for both (17) and (16) since regardless of whether the subject moves to SpecTP or not it would be in the same spell-out domain as the verb. The facts regarding stress assignment in all-new neutral sentences in German thus favor phasal spell-out. ${ }^{11}$

The arguments for full phase spell-out from Bulgarian cliticization and stress assignment in German came from the impossibility of interaction between the edge of phase XP and material outside of phase XP, which is predicted under phasal spell-out given that the two belong to different spell-out domains, in contrast to phasal complement spell-out, where the two are in the same spell-out domain. A relevant argument can in principle also be constructed by looking at potential PF interaction between a phasal head and its complement. Under phasal spell-out, such interaction should be possible (for phase-sensitive phenomena), since the two belong to the same spell-out domain. On the other hand, such interaction should be impossible under phasal complement spell-out since the two do not belong to the same spell-out domain. There are several phenomena which indicate that such interaction is possible. One case of this

11 Ishihara (2007) provides an argument for phasal spell-out based on Miyawaga's (2003) account of scopal interaction in Japanese (i)-(ii) (but see Saito 2009).

(i) zen'in-ga sono tesuto-o uke-nakat-ta. (SOV)

all-nom that test-acc take-neg-pst

'All did not take that test.' *not $>$ all, all $>>$ not (Ishihara 2007:139)

(ii) sono tesuto-o zen'in-ga $t_{i}$ uke-nakat-ta. (OSV)

that test-acc all-nom take-neg-pst

'That test, all didn't take.' not $>$ all, all $>>$ not (Miyagawa 2003:183-184)

Assuming SpecTP must be filled in Japanese, Miyagawa argues that the subject that moves to SpecTP must scope over the negation, while the negation obligatorily scopes over the subject that stays in its base position in SpecvP. The subject in (i) moves to SpecTP, hence it scopes over the negation. Miywaga argues that (ii) is structurally ambiguous. On one derivation the subject moves to SpecTP, with the object undergoing A'-movement to SpecCP. On this derivation, the subject takes wide scope. On the reading where the negation takes wide scope, the object undergoes A-movement to SpecTP, which satisfies the EPP, with the subject staying in its base position. Ishihara (2007) observes that prosody disambiguates the two readings that (ii) has. When there is a major phrase boundary after the subject, the subject must take wide scope (see (iii)), while under the prosodic phrasing in (iv), the subject cannot take wide scope. Furthermore, the unambiguous (i), where the subject moves to SpecTP, patterns with (iii) in this respect, as (v) shows.

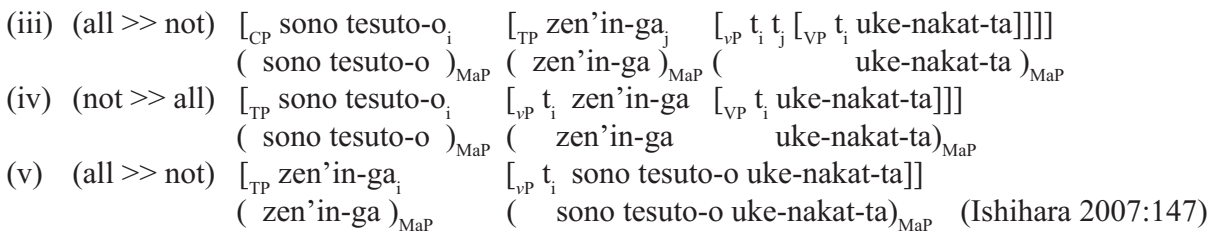

To account for these facts, Ishihara proposes that major phrases correspond to spell-out domains and that spell-out domains crucially correspond to full phases, not phasal complements. As a result, vP, not its VP complement, is sent to spell-out, hence the major phrase boundary at the edge of vP in (iii)-(v) (see Ishihara's work for details of the analysis). 
sort is raddoppiamento fonosintattico (RF) in Abruzzese, discussed in D'Alessandro and Scheer (2015), following Biberauer and D'Alessandro (2006), D'Alessandro and Roberts (2010). In RF, the initial consonant of a word undergoes gemination which is conditioned by the properties of the preceding word. In Abruzzese, a lexically conditioned set of words triggers RF when they are in a specific syntactic relationship with the following word. Importantly, the complementizer cho is an RF trigger which triggers RF on the first word within its IP complement, as shown in (18). Another relevant case is provided by (19), where RF applies between the relative pronoun in SpecCP and the subject. If RF is spell-out domain sensitive (i.e. if it cannot take place between elements in different spell-out domains), we then have evidence here that phasal complements are not spell-out domains.

(18) a) Jè mmeje cha vve.

is better that come.3sg

'It's better that he/she comes.'

b) Jè mmeje cha nni vve.

is better that not come.3sg

'It's better that he/she doesn't come.' (D'Alessandro and Scheer 2015:614)

(19) lu wagliona cha ttu si vista

the boy whom you are seen

'the boy whom you saw'

(D’Alessandro and Scheer 2015:615)

D'Alessandro and Scheer (2015) do provide evidence that RF is spell-out domain sensitive based on the impossibility of RF between the auxiliary and the participle in (20) (such RF is in principle possible, see passive (21)), which they analyze in terms of sensitivity of RF to spell-out domains. From the current perspective, (20) is analyzed as having the auxiliary outside $\mathrm{vP}$, or, more precisely, the phasal domain projected by the verb (see section 5). Since the auxiliary and the participle are then located in different phases they belong to different spell-out domains (given that phases correspond to spell-out domains), hence the impossibility of RF between the auxiliary and the participle in (20).
(20) So raspattata la legga. am.1sg respected.sg the.f.sg law.f.sg 'I have respected the law.'

(D'Alessandro and Scheer 2015:611)

While RF is blocked between the auxiliary and the participle with transitives, it is not blocked with passives (21), which is not surprising. Interestingly, it is blocked with ergatives, as in (22).

(21) So rrospattato (da tutto quində).

am.1sg respected.sg by all

'I am respected by everybody.'

(D'Alessandro and Scheer 2015:612) 
(22) so romastว.

am.1sg stayed.sg

'I have stayed.'

(D’Alessandro and Scheer 2015:613)

This pattern can be captured under full phase spell-out in the phasal system adopted below, where the phasal domain corresponds to the thematic domain. In that system, there is a phase with both unergative and ergative verbs. From this perspective, RF in passives can be captured if the auxiliary in the passive case is located in the voice head, which belongs to the thematic domain due to the absorption of the external $\theta$-role (the highest projection in the verbal thematic domain, which is actually different in the structures below, functions as a phase, see section 5). ${ }^{12}$

(23)

a) auxiliary $\left[_{\text {verbal thematic domain-vP }}\right.$ participle $]$
b) auxiliary $\left[_{\text {verbal thematic domain-VP }}\right.$ participle $]$
c) $\left[_{\text {verbal thematic domain-VoiceP }}\right.$ auxiliary participle $]$ active unergative

ergative

passive

The brackets indicate the relevant phase in (23). Since there is a phasal boundary between the auxiliary and the participle with active unergatives and ergatives but not with passives, the RF in question is possible only with passives.

As noted by an anonymous reviewer, in principle similar arguments can be provided by languages where subject clitics cliticize to a complementizer. Adrian Stegovec (p.c.) notes a case of this sort from Standard Arabic, ${ }^{13}$ which involves phonological interaction between complementizers and subject clitics (the subject in the relevant constructions must be accusative; for general discussion of clitics in Arabic, see Shlonsky 1994, 1997 and Fassi Fehri 1993, among others; on complementizers in Arabic, see these works as well as Shlonsky 2000; Fassi Fehri 1988; Khalaily 1995; and Benmamoun 2000, among others). The relevant clitics start with a consonant, and the complementizer that hosts them ends with a vowel (e.g. Panna). The only exceptional clitic in this respect is the 1p.sg one, whose exact form depends on its host. Albuhayri (2013) argues that the form of the 1p.sg ACC clitic is determined solely by the phonological properties of the host. ${ }^{14}$ The basic form of the clitic is $y a$, which is part of the strong

12 The 3p.sg form of BE, jè, triggers RF on $\mathrm{C}$ in (i). This may not be surprising in the phasal system from Bošković (2015a, 2016b), where the highest projection in the thematic domain of a lexical head and the highest projection in the non-thematic domain function as phases. Under this conception, jè actually may not start a new lexical head thematic phasal domain, which means CP would not function as a phase here (the phasehood would extend all the way to the matrix $\mathrm{CP}$ ), hence RF is possible.

(i) Chi jè cchəl'a fatto?

who is that it-has done

'Who is it that did that?' (Roberta D'Alessandro (p.c.))

13 The discussion of Arabic below is based on an analysis suggested by Adrian Stegovec (p.c.).

14 Salih (1985) and Holes (2004) argue that the clitic form depends on the category of the host. Salih suggests $i i$ occurs with prepositions and nii with other hosts, while Holes suggests nii is used with verbs and $i i$ with nouns and prepositions. The statements are, however, incorrect. Thus, nii can 
pronominal form that marks number and person information (unless otherwise noted, the data are taken from Albuhayri 2013).

(24) Piyyaa-ya = "me" (-ya = 1sg; Riyyaa = support morpheme shared by all accusative strong pronouns)

Two other forms, $i i$ and nii, are allomorphs of $y a$. Ya occurs when the host ends in a long vowel:

(25) Sașaa-ya = stick.1sg = "my stick"

$Y a$ optionally alternates with $i i$ when attached to a noun that ends in a consonant (which is not $n$ ):

(26) a) kitaab-ii -> syllabified as [ki.taa.bii] = "my book"

b) kitaab-ya $->$ syllabified as [ki.taab.ya] = "my book"

When nii surfaces, $n$ is used epenthetically. This e.g. happens with verbs with a vowel final suffix:

(27) qaabal-a-n-ii

met-perf.3m.sg-/n/-1sg

'He met me.'

Clitic pronouns must have an initial onset (they cannot be *V(V), only $\mathrm{CV}(\mathrm{V})$ ), see in this respect the syllabification in (26a)), which can in principle be satisfied in two ways in cases like (27): by deleting the short vowel of the host, or by inserting $n$. The first option is not available in (27), because deleting the vowel would make the perfective subject agreement marker unrecoverable, so the $n$-insertion strategy is used. On the other hand, with case marked nouns with a $1 \mathrm{p} . \mathrm{sg}$ ACC possessive clitic, the opposite strategy is used: since the case information is recoverable the case suffix is deleted and the clitic surfaces as $i i$ or $i y a$ (with an epenthetic $i$ vowel). ${ }^{15}$

occur with complementizers (28) and prepositions as well; compare in this respect (i) and (ii) (the issue here is that the final $n$ of the preposition cannot be resyllabified into the onset of the clitic; i.e., the alternation is phonologically conditioned, as discussed below).

(i) $\quad$ a. lii/* li-nii (li=to)

to-me

b. min-nii (min=with)

with-me

Note also that, as expected given the discussion below, prepositions ending in a long final vowel require the $y a$ clitic form ((ii) involves diphtongization of the final vowel of the preposition).

(ii) fiy-ya (fii=in, at)

15 Consider in this respect (i) (Albuhayri 2013:49); note that the nominative form would have the $-u$ ending, as in qalam- $u$ (the accusative is qalam- $a$ and genitive qalam-i). 
The main point here is that all clitic forms can be determined from phonological information and the different strategies that can be employed so that the host+clitic sequence fits one of the syllabification templates of Arabic. Albuhayri (2013) does not discuss the relevant complementizer+clitic constructions, but Adrian Stegovec (p.c.) observes that there is phonological interaction between the two. The complementizers that trigger subject cliticization are Pinna and Panna. The clitic form that is used with the complementizers is nii, as in (28). ${ }^{16}$

$$
\begin{aligned}
& \text { (28) qaal-at Pinna-nii ðahab-tu Pila l-qaryat-i } \\
& \text { said-3f.sg that-1sg.acc went-1sg to the-village-obl } \\
& \text { 'She said that I went to the village.' }
\end{aligned}
$$

What is of interest here is that the complementizer is neither VV-final nor C-final. The relevant complementizers are morphologically complex. Panna has a counterpart that does not co-occur with a clitic, Pan. Khalaily (1995) in fact analyzes the complementizer as being composed of Pan and na. As for Pinna, Benmamoun (2000) notes the - $n a$ segment is a focus particle ( Pinna is an emphatic complementizer), a treatment that can also be applied to Panna. Adrian Stegovec (p.c.) observes that, given this, the -na part of these complementizers cannot be deleted when the $1 \mathrm{p} . \mathrm{sg}$ clitic is attached to make the host + clitic fit a syllabic template. This is because $n a$ is a separate morpheme, which cannot be recovered upon deletion. Instead, the epenthetic $n$ is inserted, so the clitic surfaces as nii. What is important here is that the form of the complementizer affects the PF realization of the clitic.

It should be noted that Palestinian Arabic may be different in this respect. Thus, Shlonsky (1994:2) gives examples where the form of the complementizer changes when a clitic is attached:
(29)
a) Pinnu l-mћalme
b) Pin-ha that the-teacher that-she

The Pinnu complementizer which otherwise does not appear in the short form surfaces as Pin when a subject accusative clitic is attached. (29) from Palestenian Arabic is then another case of complementizer-clitic phonological interaction, where, in contrast

\footnotetext{
(i) haaðaa qalam-ii /-i-ya.

this pen(nom)-1sg.acc

'This is my pen.'
}

Note there is no case deletion with non-1sg possessive clitics; thus, the nominative surfaces in (ii) (Albuhayri 2013:71).

(ii) haaðaa bayt-u-ki this house-nom-2sg.fem.acc

'This is your house.'

16 There are other complex complementizers that trigger cliticization which are also based on either Pinna or Panna. 
to the Standard Arabic cases discussed above where the form of the clitic is affected, the form of the complementizer is affected.

At any rate, what is important for us is that we have here a case of phonological interaction between a complementizer and the material in its complement. If such interaction is spell-out domain sensitive, i.e. if it cannot take place between elements in different spell-out domains, we have another argument here that what is sent to spellout is not the complement of a phasal head.

In Bošković (2016c) I give another argument to this effect based on tone sandhi in Taiwanese, in particular, cases like (30), where tone sandhi, indicated by $\bullet$, applies between the Comp kong and its IP complement. Tone sandhi, which Bošković (2016c) and Simpson and $\mathrm{Wu}(2002)$ show is spell-out domain sensitive, in (30) applies between a phasal head and its complement (see Bošković 2016c for an account of the full paradigm, including the data noted in Simpson and $\mathrm{Wu} 2002$ ).

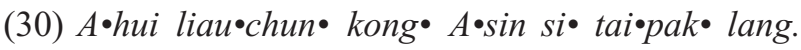

Ahui thought $\mathrm{C}$ Asin is Taipei person

'A-hui thought that A-sin is from Taipei.'

(Simpson and Wu 2002:79)

To summarize, the phenomena discussed in this section illustrate the impossibility of PF interaction between the edge of phase XP and material outside of phase XP, as well as the possibility of PF interaction between the edge of phase XP and the complement of X, a state of affairs which is expected under phasal spell-out, but not under phasal complement spell-out.

It is also worth noting that early pre-phasal approaches to prosodic phrasing (e.g. Nespor and Vogel 1986; Selkirk 1986) have anticipated phasal spell-out, not phasal complement spell-out. Thus, the standard assumption in these approaches to prosodic structure, which is taken to be determined by (though it does not completely correspond to) the syntactic structure, is that the left edge of a $\mathrm{CP}$ corresponds to an intonational phrase boundary. In other words, the correspondence here is with a phase, not a phasal complement. This is natural if spell-out domains correspond to phases. If they don't, we would have a rather strange situation where the prosodic domain would not correspond to what is sent to spell-out. What would be sent to spell out would be the IP below $\mathrm{CP}$ and the VP above the $\mathrm{CP}$, but the correspondence would be with the "sandwiched" phrase, CP.

\section{MULTIPLE SPELL-OUT AND SUCCESSIVE-CYCLIC MOVEMENT}

I now turn to the interaction of multiple spell-out and successive cyclic movement (SCM), which raises an interesting problem. If both multiple spell-out and SCM were to be defined strictly on phases, phases would be spell-out units and SCM would target phases. A problem, however, would then arise. It is standardly assumed that what is sent to spell-out is no longer accessible to the syntax. Given this assumption, it is simply not possible to state the domain for both spell-out and SCM in terms of phases. 
If SCM were to target spell-out units, the element undergoing movement would get frozen with the first step of SCM since it would be part of a spelled-out unit, hence no longer accessible for syntactic operations. Either spell-out or SCM can then be stated in terms of phases, but not both. What we in fact need is the following: In (31), where XP is the first phrase above YP and these phrases are affected by SCM and spell-out, YP should be the spell-out domain, and XP should be targeted by SCM (with YP spelled out after that movement). Furthermore, only one of these should correspond to phases.

$$
\text { (31) }\left[_ { \mathrm { XP } } \left[_{\mathrm{YP}}\right.\right.
$$

The issue here is which of the two, XP or YP, should be a phase; i.e. the issue is whether the domain for SCM or the domain for spell-out should correspond to phases. In Chomsky (2001), XP is the phase; i.e. the domain for SCM is defined on phases, the domain for spell-out is not. In principle, it could be exactly the other way round, with YP being a phase, not XP. The domain for spell-out would then be defined on phases, instead of the SCM domain. In the next section, I will argue for this kind of a system; in particular, I will argue that this approach is preferable on both empirical and conceptual grounds to Chomsky's (2001) system, which is based on phasal complement spellout. The main argument will involve a generalization concerning locality domains for movement established in Bošković (2015a). I will therefore first make a digression to discuss the generalization in question.

\subsection{On the Complex NP Constraint and the lack of the Complex VP Constraint}

Since Ross (1967) posited (32), illustrated by (33), where complex NP is a noun modified by a clause, ${ }^{17}$ not much attention has been paid to an obvious contrast: While extraction from complex NPs is disallowed, extraction from such VPs is allowed, as shown by (34). In other words, there is Complex NP Constraint, but there is no Complex VP Constraint.

(32) The Complex NP Constraint (CNPC): Extraction from complex NPs is disallowed.

(33) *How ${ }_{i}$ did you hear $\left[{ }_{\mathrm{NP}}\right.$ rumors $\left[{ }_{\mathrm{CP}}\right.$ that $\left[{ }_{\mathrm{IP}}\right.$ John bought a house $\left.\left.\left.t_{i}\right]\right]\right]$ ?

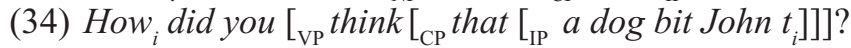

The standard research strategy within the Minimalist Program has been to focus on (34), putting (33) aside, with the theories of the locality of movement built on the basis of (34). Bošković (2015a), however, argues this research strategy has been misguided since (33) represents a pervasive pattern found in many contexts, while (34) is highly

17 I will ignore relative clauses, which involve extraction from adjuncts. (Note also that Safir 1985 shows that (32) cannot be reduced to the adjunct condition by treating nominal clausal complements as appositives/adjuncts.) 
exceptional. Thus, extraction is banned not only from clausal, but all complements of Ns. Furthermore, APs, PPs, even ergative VPs pattern with NPs in this respect. I will briefly summarize the relevant data in the following section, restating the descriptive generalization reached in Bošković (2015a) based on these data in phase-theoretic terms. Section 5.2 will give a deduction of the generalization, where a phase is completely inaccessible to a higher phasal head, with no edge/PIC exception. ${ }^{18}$ The crucial component of the deduction will be phasal spell-out, i.e. that what is sent to spell-out is phases, not phasal complements.

\subsubsection{On the Complex XP Constraint ${ }^{19}$}

The CNPC concerns clausal complements. However, extraction is banned not only from clausal complements of nouns, but all complements of nouns. Observe in this respect (36) and (38), which contrast with (35) and (37) (such contrasts were noted in Bach and Horn 1976 and Chomsky 1973). ${ }^{20}$ Note that I assume a reanalysis/pruning account of P-stranding, where there is no PP in (37), hence like (35), (37) involves extraction of the nominal complement, in contrast to (38), which involves extraction out of it. (Section 5.4 actually gives an account of P-stranding where there is PP in (37) but its effects are voided so that for all intents and purposes friends of behaves like a complex head that takes $t_{i}$ as its complement; pending section 5.4 I will put P-stranding aside.)

(35) Of who (m) did you see [friends $\left.t_{i}\right]$ ?

(36) ??Of who $(m)_{i}$ did you see $\left[_{\mathrm{NP}}\right.$ enemies of friends $\left.t_{i}\right]$ ?

(37) Who did you see [friends of $\left.t_{i}\right]$ ?

(38) ?*Who ${ }_{i}$ did you see $\left[_{\mathrm{NP}}\right.$ enemies of friends of $\left.t_{i}\right]$ ?

Consider now Greek, where both genitive DPs and PPs function as nominal complements. Both cases exhibit a simple/deep extraction contrast, extraction being disallowed from the nominal complement, as illustrated below for the former. (40), which involves extraction out of a nominal complement, contrasts with (39), which involves extraction of a nominal complement.

18 See Bošković (2015a) for an alternative account based on Chomsky's (2013) labelling system, and Bošković (2016a) for an account based on a contextual approach to phases where X functions as a phase only after it is embedded into structure. The accounts in question do not differ only theoretically, they are also not equivalent empirically (see Bošković 2016a); I will, however, not compare them here since that would go beyond the main goal of this article.

19 This section sums up some of the arguments from Bošković (2015a); see that work for additional arguments. Since weak islands are sometimes completely weakened with argument extraction, adjunct extraction is more reliable, hence will be used whenever possible (another interfering factor with argument but not adjunct extraction concerns reanalysis and phase collapsing from section 5.4, see Bošković 2015a). However, in English it can be tested only with clausal complements, even *From which city ${ }_{i}$ did Peter meet [ girls $_{i}{ }_{i}$ ] being disallowed (see Chomsky 1986).

20 Since we are dealing here with argument extraction the locality violations are weaker (note that only the relevant NP in the unacceptable examples is marked). 
(39) tu vivliu $u_{i}$ mи ipes pos dhiavases tin [kritiki $t_{i}$ ] the.gen book.gen me said.2sg that read.2sg the review 'You told me you read the review of the book.' (Horrocks \& Stavrou 1987) (40) *tu vivliu ${ }_{i}$ mu ipes pos dhiavases (tin) $\left[_{\mathrm{NP}}\right.$ enstasi $\left[_{\mathrm{DP}}\right.$ tis kritikis $\left.\left.t_{i}\right]\right]$ the.gen book.gen me said.2sg that read.2sg the objection the.gen review.gen 'You told me you read the objection to the review of the book.'

Turning to French combien-extraction, while simple combien-extraction, where the DP is a verbal complement, is allowed, deep combien-extraction, where the DP is a complement of a noun, is not. The unacceptable (42) also involves extraction out of a nominal complement.

(41) Combien ${ }_{i}$ a-t-il consulté $\left[_{\mathrm{DP}} t_{i}\right.$ de livres $]$ ? how.many has-he consulted of books

(42) * Combien a-t-il consulté $\left[_{\mathrm{DP}}\right.$ (plusieurs/des) $\left[_{\mathrm{NP}}\right.$ préfaces $\left[_{\mathrm{DP}} t_{i}\right.$ de livres $\left.\left.]\right]\right]$ how.many has-he consulted several/some prefaces of books 'How many books did he consult several/some prefaces of?'

Being rather liberal regarding extraction from NPs, Serbo-Croatian (SC) provides several relevant cases. SC allows extraction of adjectives (43) and NP-adjuncts (45). Importantly, both are blocked when the NP from which extraction occurs functions as a nominal complement, as in (44) and (46).

(43) Pametne ${ }_{i}$ on cijeni $\quad\left[t_{i}\right.$ prijatelje $]$ smart he appreciates friends

(44) * Pametnih $_{i}$ on cijeni $\quad\left[{ }_{\mathrm{NP}}\right.$ prijatelje $\left[t_{i}\right.$ studenata $\left.]\right]$ smart he appreciates friends students 'He appreciates friends of smart students.'

(45) Iz kojeg grada je Petar sreo [djevojke $\left.t_{i}\right]$ ? from which city is Peter met girls

(46) *Iz kojeg grada ${ }_{i}$ je Petar kupio $\left[_{\mathrm{NP}}\right.$ slike [djevojke $\left.\left.t_{i}\right]\right]$ ? from which city is Peter bought pictures girl 'From which city did Peter buy pictures of a girl?'

A variety of extractions thus shows that extraction from the complement of a noun is disallowed. There is then nothing special about CPs here; extraction from a nominal complement is disallowed regardless of its category. We then have the Generalized Complex NP Constraint in (47).

(47) Extraction out of nominal complements is disallowed.

Consider now other lexical heads, starting with adjectives and the CNPC context. Adjectives also display the effect in question: (48) is unacceptable if the adjunct modifies the embedded clause. 
(48) $* H_{1} /$ Why $y_{i}$ are you $\left[_{\mathrm{AP}}\right.$ proud $\left[_{\mathrm{CP}}\right.$ that John hired Mary $\left.\left.t_{i}\right]\right]$ ?

Extraction is also banned from non-CP complements of adjectives, as the contrast in (49) shows.

(49) a. Of who(m) is he [proud $\left.t_{i}\right]$ ?

b. *Of who $(m)_{i}$ is he $\left[_{\mathrm{AP}}\right.$ proud of $\left[\right.$ friends $\left.\left.t_{i}\right]\right]$ ?

Returning to Greek, like nouns, adjectives can take either genitive DP or PP complements in Greek. In both cases, extraction from the complement of responsible is banned.

(50) *Tu ktiriu ${ }_{i} \quad\left[\right.$ AP $_{\text {ipefthinos }}\left[\right.$ tu fotismu $t_{i} /$ gia to fotismo $\left.\left.t_{i}\right]\right]$ the.gen building.gen is.responsible the.gen lighting.gen/for the lighting 'the building he is responsible for the lighting of'

We then have the Generalized Complex AP constraint.

(51) Extraction out of adjectival complements is disallowed.

The same holds for PPs. (52) replicates the simple/deep extraction contrast from NPs/APs.

(52) a. Who did you read [about $\left.t_{i}\right]$ ?

b. *Of who $(m)_{i}$ did you read $\left[_{\mathrm{pP}}\right.$ about friends $\left.t_{i}\right]$ ?

Prepositions can take CP complements in Spanish. Significantly, they also disallow extraction. ${ }^{21}$

$*_{\text {¿cómo }}$ se acordó $\quad{ }_{\mathrm{PP}}$ de $\left[_{\mathrm{CP}}\right.$ que [Pedro preparaba la comida $\left.\left.t_{i}\right]\right]$ how clitic (s)he.remembered of that Pedro prepared.imperf the food

Greek (54) confirms the existence of the Generalized Complex PP Constraint, given in (55).

(54) * Tinos $_{i}$ endhiaferese $\quad\left[{ }_{\mathrm{pP}} y a\left[\right.\right.$ ti fili $\left.\left.t_{i}\right]\right]$ who.gen be.interested.2sg for the friend

'Whose friend are you interested in?'

(Horrocks \& Stavrou 1987)

(55) Extraction out of complements of prepositions is disallowed.

21 Some languages treat (some) Ps as inherent Case-markers (see Nunes 2009). Such Ps are not relevant to our concerns. 
Before we address the obvious question, why are VPs different here, it is important to note that they are not always different. The effect in question is actually found with ergative VPs. Thus, (56), involving a non-ergative verb, is better than (57), involving an ergative verb.

(56) Who did they see (some) friends of t yesterday?

(57) ?*Who did there arrive (some) friends of $t_{i}$ last week?

Turning to ergatives taking CP arguments, consider (58)-(59). They involve uncontroversially ergative psych verbs, where the $\mathrm{CP}$ is located in the V-complement position (see Belletti \& Rizzi 1988; Pesetsky 1995; Landau 2010). ${ }^{22}$ Importantly, both argument and adjunct extraction are degraded here, the latter being worse, as expected. ${ }^{23}$

(58) a. ?? What did it appeal to Mary [that John fixed $\left.t_{i}\right]$ ?

b. *How ${ }_{i}$ did it appeal to Mary [that John fixed the car $\left.t_{i}\right]$ ?

(59) a. ?? What ${ }_{i}$ did it depress Mary [that John sold $\left.t_{i}\right]$ ?

b. ${ }^{*}$How $_{i}$ did it depress Mary [that John was fired $\left.t_{i}\right]$ ?

There are also transitive ergatives that do not take $\mathrm{CP}$ arguments, where only argument extraction can be checked (see footnote 19). Extraction is also degraded in such cases (see also Belletti and Rizzi 1988 for Italian).

(60) ?? Who ${ }_{i}$ did your behavior bother [the sister of $\left.t_{i}\right]$ ?

(61) ?*Who did John's embarrassment escape [friends of $t_{i}$ ]?

(Johnson 1992)

The Generalized Complex VP Constraint effects thus emerge with ergative verbs.

(62) Extraction out of complements of ergative verbs is disallowed.

When properly generalized, the CNPC thus represents a pervasive pattern found in many contexts. Extraction is banned not only from clausal but all nominal complements. APs, PPs, and ergative VPs pattern with NPs. ${ }^{24}$ In other words, with the exception of non-ergative Vs, extraction is banned from complements of lexical heads.

(63) The Complex XP Constraint (where $X \neq$ non-ergative $V$ ) Extraction out of complements of lexical heads is disallowed.

22 For ergatives with just CP arguments, see Bošković (2015a), where it is shown that when some interfering factors are controlled for they also show Complex VP Constraint effects.

23 (58)-(59) may involve short V-movement, which may exist in English independently of v (Johnson 1991; Lasnik 1999)

24 See Bošković (2015a) on passives. 


\subsubsection{Restating the Complex XP Constraint}

This section restates (63) within the phase theory of Bošković (2015a). A deduction of the phase-theoretic restatement of (63) will then be presented that is crucially based on phasal spell-out.

In Chomsky (2000), certain phrases are always phases regardless of their syntactic context. Many have, however, argued that the phase status of X can be affected by its syntactic context. Thus, Bošković (2013a, 2014) argues that the highest projection in the extended domain of a lexical head functions as a phase. There, $\mathrm{vP}$ is a phase as the highest projection in the extended domain of $\mathrm{V}$. There is a phase even with ergatives even if $\mathrm{vP}$, which is responsible for external $\theta$-role assignment, is absent; $\mathrm{VP}$ is then the phase as the highest projection in the domain of V. One issue, however, that arises with this approach concerns what counts as the extended domain of a lexical category. Consider V. Bošković (2013a) takes vP to close the extended domain of V. Wurmbrand (2014) proposes a modification of Bošković's (2013a) approach where AspectP is also included in this domain, which was also adopted in Bošković (2014). Grimshaw's (1990) approach to extended projections would extend the domain of V even further. What this shows is that determining exactly what counts as the extended domain of a lexical category (at least with verbs) is not straightforward. Bošković (2015a), however, proposes a modification that eschews this issue. Taking as the point of departure Grohmann (2003), where a clause is divided into three domains, the discourse, the agreement, and the $\theta$-domain, Bošković (2015a) proposes to collapse the agreement and the discourse domain into one domain, giving us two domains: thematic and nonthematic. What is relevant for our purposes here is the former. The proposal is that the thematic domain of each lexical category corresponds to a phasal domain, where the highest projection in the domain functions as a phase, as in Bošković (2013a). The departure from Bošković $(2013 \mathrm{a}, 2014)$ here is that the thematic domain replaces the murkier notion of extended domain. $\mathrm{vP}$ is then a phase as the highest projection in the thematic domain. With ergatives, due to the lack of $\mathrm{vP}, \mathrm{VP}$ is the highest projection in the thematic domain hence a phase. Notice that the presence of a non- $\theta$-marking $v P$ with ergatives would not affect anything here: VP would still be a phase (for this reason I will ignore the issue in question below). This is in contrast to Bošković (2013a, 2014), where the presence of a non- $\theta$-marking vP would actually void VP of phasehood. ${ }^{25}$

Now, assuming the approach to phasehood where the highest projection in the thematic domain of every lexical head functions as a phase, it turns out that all the examples that instantiate (63) actually involve the context in (64), where a phasal head takes a phase as its complement. ${ }^{26}$

25 I assume that whether or not an external $\theta$-role is to be assigned is indicated in the $\theta$-grid of the verb (even when it is assigned in SpecvP; see here Sawada 2015), which means that the phasal status of VP (i.e. whether or not VP is a phase) can be determined locally (depending on whether all the $\theta$-roles in the $\theta$-grid of the verb are assigned). Following standard assumptions, I also assume that a $\theta$-marked externally merged Spec of XP is created before successive-cyclic movement can target the edge of XP. The reader should bear these points in mind during the discussion below.

Following standard assumptions, I assume that CPs and DPs are also phases. 
To illustrate, NP is a phase in (33) as the highest projection in the nominal thematic domain. The same holds for AP in (48) and PP in (53), where AP and PP are the highest projections in the $\mathrm{A} / \mathrm{P}$ thematic domains. Focusing on the nominal case, the noun takes CP, which is a phase, as its complement in (33). This means that (33) involves the double-phase context from (64). The same holds for Greek (40), where there is a DP phase right below the NP phase. In fact, all the cases of the Generalized Complex NP Constraint discussed above involve (64). The same holds for the Generalized Complex AP Constraint. The adjective, a phase head, takes a CP phase complement in (48) and a DP/PP phase complement in Greek (50). The same holds for the Generalized Complex PP Constraint. The preposition, a phasal head, also takes a phasal complement in all the relevant cases (see (52)-(54)). Consider finally the VP cases, i.e. (56)-(61). As discussed above, ergative verbs behave differently from non-ergative verbs in that they show Complex XP Constraint effects (i.e. there is a Generalized Complex VP effect with ergative verbs). The obvious conclusion is that $\mathrm{vP}$ is what matters here, which follows from the current phasal system. With non-ergative verbs, vP is the highest projection in the verbal thematic domain. This means VP is not a phase with nonergative verbs. As a result, extraction from clausal complements of non-ergative verbs, as in (65), does not involve (64). In contrast, ergatives lack the thematic vP layer. This means that VP is the highest (and only) projection in the relevant thematic domain hence a phase in (66). (66) then involves a double-phase configuration. (Phases are given in boldface. For ease of exposition, I ignore V-movement here; recall also that the potential presence of a non- $\theta$-marking $\mathrm{vP}$ would not affect anything here, hence it is ignored below).

(65) How ${ }_{i}$ did you $\left[_{\mathrm{vP}} t_{i}\left[_{\mathrm{VP}}\right.\right.$ think $\left[_{\mathrm{CP}} t_{i}\right.$ that $\left[_{\mathrm{IP}}\right.$ John $\left[_{\mathrm{vP}}\right.$ fixed the car $\left.\left.\left.\left.\left.t_{i}\right]\right]\right]\right]\right]$ ?

(66) $*{ }^{*}$ How $_{i}$ did it $\mathrm{I}_{\mathrm{VP}} t_{i}$ appeal to Mary $\mathrm{I}_{\mathrm{CP}} t_{i}$ that $\left[_{\mathrm{IP}}\right.$ John $\left[_{\mathrm{VP}}\right.$ fixed the car $\left.\left.\left.\left.t_{i}\right]\right]\right]\right]$ ?

Extraction is thus disallowed in the configuration in (64), where a phasal head takes a phase as its complement. (63) can then be restated as in (67). ((67) will be slightly revised below).

(67) The Phase-over-Phase Constraint: Extraction is banned from phases that function as complements of phasal heads (i.e. the double-phase configuration in (64)).

Before proceeding with the account of (67), it is worth pausing here to address the obvious question the current discussion raises: why is there no Complex VP Constraint, in contrast to the Complex NP Constraint, the Complex AP Constraint and the Complex PP Constraint. A clue here is provided by the existence of the Complex VP Constraint effect with ergatives. The obvious difference between ergative and non-ergative verbs is the existence of ( $\theta$-marking) $\mathrm{vP}$ with the latter. (67) capitalizes on this: the current approach to phases yields a principled difference (deduced below) between ergative 
and non-ergative verbs given the presence of vP with the latter. Generalizing the VP situation, the reason for the contrast between acceptable (34) and ill-formed (33)/(48)/ (53)/(58b), i.e. the reason for the different behavior of non-ergative VP and NP/AP/PP/ ergative VP regarding the Complex XP Constraint, is the presence of vP, i.e. the assignment of the external $\theta$-role in a projection distinct from VP. There is then no such projection with NP/AP/PP. ${ }^{27}$

(67) restates (63) in phase-theoretic terms. The two are actually not equivalent empirically. Although all the cases discussed so far are captured by both (63) and (67), there are cases that can tease them apart. One such case involves AP extraction. Recall SC bans deep AP extraction, as in (44). Both (63) and (67) capture (44), the relevant structure of which prior to AP extraction is given in (68) (following Bošković 2012, I assume that SC lacks DP (though this is not crucial here)).

$$
\begin{gathered}
\text { (68) } \ldots\left[_{\mathrm{NP}} \text { prijatelje }\left[{ }_{\mathrm{NP}} \text { pametnih studenata }\right]\right] \\
\text { friends } \text { smart students }_{\mathrm{GEN}}
\end{gathered}
$$

The noun here assigns genitive, which is the structural case assigned by nouns in SC (Franks 1994; Bošković 2013a). However, nouns that assign inherent case allow deep AP extraction (deep adjunct extraction from (46) is also allowed with inherent case assigning nouns, see Bošković 2013a).

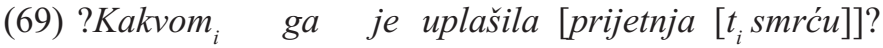 what-kind-of him is scared threat death ${ }_{\text {INSTR }}$ 'Of what kind of death did a threat scare him?'

(Bošković 2013a)

Bošković (2013a) argues that inherent case-assignment involves a dummy linkerlike projection FP, as in the structure in (70). ${ }^{28}$ The higher noun here takes FP as its complement, with $\mathrm{F}$ in turn taking the lower NP as its complement.

\section{(70) $\ldots\left[_{\mathrm{NP}}\right.$ prijetnja $\left[_{\mathrm{FP}}\left[{ }_{\mathrm{NP}}\right.\right.$ kakvom smrću $\left.\left.]\right]\right]$}

Notice now that (69) still violates (63) since it involves extraction from the complement of a lexical head. However, assuming that due to its nature the dummy linker projection is not a phase, we don't have a phase-over-phase configuration here. The case in question then differentiates (63) and (67), favoring (67) (but see Talić 2013; note also that (69) is consistent with the deduction of (67) below).

$27 \mathrm{nP} / \mathrm{pP} / \mathrm{aP}$ are often posited for the sake of uniformity with VP. But the fact is that there is no uniformity here at all regarding extraction. Notice, however, that $\mathrm{n} / \mathrm{p} / \mathrm{aP}$ can still exist, they just would not be part of the thematic domain (i.e. they would not be assigning a $\theta$-role; see Bošković 2015a for relevant discussion).

28 Bošković (2013a) basically follows here the long-standing intuition that inherent case assignment involves a preposition-like element, which is implemented through the presence of FP in $(70)$. 
Having restated (63) in phase-theoretic terms, which turned out to be preferable to (63) on empirical grounds (see footnote 39 for another relevant case), I turn to the deduction of (67).

\subsection{Deducing the ban on extraction in phase-over-phase configurations}

A clue for deducing (67) can be found in Chomsky's (2001) approach to the PIC. While in Chomsky (2000), when a phase is assembled only its edge is accessible to anything outside of the phase (due to the PIC), for Chomsky (2001) the PIC effect does not kick in immediately; it kicks in only when the next phase head is merged. As a result, the complement of a phase head is accessible to the next head if that head is not a phasal head. However, it is inaccessible if that head is a phasal head. This kind of distinction between phasal and non-phasal heads is exactly what we need. Recall that extraction from a phase is disallowed if the phase is merged with a phasal head, but not if it is merged with a non-phasal head. What we then need is to modify Chomsky's (2001) approach to the PIC in a way that still makes a difference between phasal and non-phasal heads regarding the accessability of a phase they are merged with. In particular, the edge of a phase needs to be accessible only to non-phasal heads; a phase needs to be completely inaccessible to the next phasal head. This can be captured if the PIC holds only for non-phasal heads. It can then be used as a gate for movement only if the head merged with a phase is a non-phasal head. This means that the edge of phase XP in (71) is accessible to the non-phasal head Y, but not to the phasal head Z.

(71) $\mathbf{Z}(\mathrm{Y})\left[{ }_{\mathrm{XP}}\right.$ wh $\left.\mathbf{X}\right]$

In (33)/(72), how then moves to the embedded SpecCP, CP being a phase. However, since $\mathrm{CP}$ is now completely inaccessible when the next phasal head is merged, when $\mathrm{N}$, a phasal head, is merged, how can no longer move.

(72) $\mathrm{N}\left[{ }_{\mathrm{CP}}\right.$ how $\left.\mathrm{C}\left[{ }_{\mathrm{IP}} \ldots ..\right]\right]$

How also moves to the embedded SpecCP in (34). However, the head merged with the $\mathrm{CP}$ in (34)/(73a) is not a phasal head. This means that how, located at the CP phase edge, is accessible for movement to V. V then attracts how, which moves to SpecVP. Since VP is not a phase, in contrast to how in (72), how in (73b) is accessible to the next phasal head (v), hence can move to its edge.

(73) a. $\mathrm{V}\left[{ }_{\mathrm{CP}}\right.$ how $\left.\mathrm{C}\left[{ }_{\mathrm{IP}} \cdots . ..\right]\right]$

b. $\mathrm{V}\left[{ }_{\mathrm{VP}}\right.$ how $\mathrm{V}\left[{ }_{\mathrm{CP}}\right.$ how $\left.\left.\mathrm{C}\left[{ }_{\mathrm{IP}} \ldots . ..\right]\right]\right]$

While the account works, it is rather stipulative: why would the PIC hold only for non-phasal heads?

Recall, however, what is needed here: a phase needs to be completely inaccessible at the next phasal level, i.e. when the next phasal head is merged, with no PIC loophole. 
There is actually a rather natural way of accomplishing this if we assume that what is sent to spell-out is phases, not phasal complements. Furthermore, we will see that the phasal spell-out account enables us to dispense with the PIC completely (in contrast to the analysis outlined above).

What we need here is to close the PIC loophole in one context. The most natural way of closing that loophole is to eliminate the PIC loophole altogether. Suppose then that there is nothing like the PIC in the syntax. Under multiple spell-out, pieces of syntactic structure are transferred to the interfaces during the derivation. Assuming that what is transferred to the interfaces is no longer accessible in the syntax, there is no need to have anything like the PIC holding as a principle in the syntax itself, structure that is spelled-out will anyway be inaccessible in the syntax.

Recall now that in the original proposal regarding phases, what was sent to spellout was the phase itself. The assumption was later modified in that what was sent to spell-out was the phasal complement. As discussed above, this resulted in a rather strange situation: while theoretically, phases are the crucial units in the multiple spell-out framework, for all practical purposes the crucial units are actually phasal complements. But, in contrast to phases, phasal complements have no theoretical status, as can be easily seen by comparing the great deal of effort that has gone into coming up with the proper definition of what counts as a phase with no attempts whatsoever of that kind regarding phasal complements. The reason is of course simple: phasal complements have no theoretical status, only phases do. They should then play no role in spell-out, what is transferred to spell-out should be phases. Recall also that arguments for multiple spell-out regarding PF phenomena favor phasal spellout (see section 4), that phasal spell-out fits more naturally with the labeling theory, where labeling is interface-driven and what is being labeled is phases, and that it is also simpler in that only phases are ever sent to spell-out under the phasal spell-out approach while under the phasal complement spell-out approach spell-out still targets phases with matrix clauses.

Let us then assume that what is sent to spell-out is phases, not phasal complements. However, following Chomsky (2001) (but adapting it to phasal spell-out), a phase is transferred to spell-out when the next phasal head enters the structure. In particular, following Bošković (2014), the transfer takes place as soon as the next phase head is merged. This analysis, which does not require the PIC at all and privileges phases, not phasal complements, for spell-out, accounts for (67). The gist of it is that the wh in (74) is accessible to $\mathrm{Y}$, a non-phasal head, but not to $\mathrm{Z}$, a phasal head, because merger of $\mathrm{Z}$ triggers immediate spell-out of the XP phase.

(74) $\mathbf{Z}(\mathrm{Y})\left[_{\mathrm{XP}} w h\right]$

Let us apply this analysis to concrete cases. (33), a CNPC case, is straightforward. As soon as N, a phasal head, is merged, CP is sent to spell-out. As a result, nothing within $\mathrm{CP}$ is accessible for movement from $\mathrm{CP}$, hence how cannot move out of it (it doesn't actually matter whether how moves to SpecCP or not). 
(75) $\mathbf{N}\left[{ }_{\mathrm{CP}} \ldots\right.$ how ... $]\left({ }^{*}\right.$ How $_{i}$ did you hear $\left[_{\mathrm{NP}}\right.$ rumors $\left[_{\mathrm{CP}}\right.$ that John bought a house $\left.\left.\left.t_{i}\right]\right]\right)$

In (34), CP merges with $\mathrm{V}$, which is not a phasal head, in contrast to the head CP merges with in (33). CP is then not sent to spell-out in (34)/(76a). This means that how is accessible for movement to $\mathrm{V}$. (If its base position is above $\mathrm{vP}$, how is accessible to $\mathrm{V}$ in its base position.) How then moves to SpecVP. ${ }^{29}$ Merger of $\mathrm{v}$ triggers spell-out of the lower phase, CP. However, since how has already moved out of it, it is not affected by the CP spell-out in (76), in contrast to (75).

(76) a. $\mathrm{V}\left[\left[_{\mathrm{CP}} \ldots\right.\right.$ how... $]$
b. $\mathbf{v}\left[\begin{array}{ll}\mathrm{VP} \\ \text { how } \mathrm{V}\left[{ }_{\mathrm{CP}}\right.\end{array}\right.$

The contrast between (33) and (34) is thus captured. The analysis extends to all other cases of (67).

The account has interesting architectural consequences. What is sent to spell-out is full phases. However, what is targeted by successive-cyclic movement (SCM) is not phases, but phrases above them. (In (76), the movement targets the first phrase above vP (see Bošković and Lasnik 2003; Lahne 2008; Den Dikken 2009a for arguments for such movement) and VP; unless additional assumptions are adopted, movement need not pass through phasal edges. $)^{30}$

29 See here Rackowski and Richards (2005) and den Dikken (2009a,b), who also argue that successive-cyclic movement in (34) does not go through SpecCP (for them, the movement also targets the VP domain above CP; note also that the standard reconstruction arguments for a phase in the VP domain with both unergative and ergative verbs of the kind discussed in Fox (1998) and Legate (2003) extend to the current approach to the locality-of-movement in this domain).

30 There are many empirical arguments for successive cyclic movement, which quite conclusively show that movement proceeds in this manner. While that much is clear, it is much harder to use the relevant tests to determine the exact landing sites. Thus, while the cases where movement has a morphological reflex on the verb (which is often the case) argue for successive cyclic movement through the VP domain, as is crucially the case under the current analysis, it is difficult to use them to pin-point its exact landing site. There are also cases which have been used to argue that movement proceeds via SpecCP. While nothing would go wrong in the current system if such movement occurs, the system does not require it. Importantly, all the relevant cases have been quite convincingly argued not to involve successive-cyclic movement through SpecCP; i.e. a closer scrutiny of such cases has revealed that they either involve terminal movement to Spec$\mathrm{CP}$, no movement at all, or successive-cyclic movement via positions other than SpecCP (e.g. the well-known case of agreeing intermediate Cs in Kinande turns out not to involve movement; all movement diagnostics, like reconstruction and islandhood, fail with such cases; some cases that have been traditionally assumed to involve intermediate wh-agreement do not even exhibit such agreement; thus in many languages wh-movement affects the agreement relationship holding between the verb and the intermediate complementizer - it is not the case that the wh-phrase itself agrees with the $\mathrm{C}$; at any rate, there are quite a few works arguing that languages that have been traditionally claimed to involve Spec-Head agreement between a wh-phrase and an intermediate C have been misanalyzed, see e.g. Boeckx (2004), Bošković (2008), Schneider-Zioga (2009), Rackowski and Richards (2005), Lahne (2008), Finer (2003), Noonan (1999) and especially den Dikken (2009a,b). Regarding other types of more direct arguments for successive cyclic move- 
An appealing property of the phase system is that phases are relevant to many phenomena. However, as discussed above, there is a problem with spell-out and SCM in this respect. Given that what is sent to spell-out is no longer accessible to the syntax, it is simply not possible to state the domain for both spell-out and SCM in terms of phases. If SCM were to target spell-out units, the moving element would get trapped and prevented from further movement since it would be part of a spelled-out unit. Only one of the two mechanisms, spell-out or SCM, can then be stated in terms of phases: for a moving element not to get caught in a spell-out unit, either the domain for SCM or the domain for spell-out can correspond to phases, but not both. This in fact is the property of both Chomsky (2001) and the current system. They both have the following property: XP is sent to spell-out and movement targets YP right above it. In both systems, one of the two is defined on phases. The difference between the two is which mechanism is defined on phases. For Chomsky, it is SCM: SCM targets phases, spell-out doesn't. ${ }^{31}$ In the current system, spell-out targets phases, SCM doesn't. In this respect, the systems seem equal conceptually. What we are, however, dealing with here is an issue of primacy: what should be privileged, spell-out or SCM. By defining the former on phases, with SCM piggy-backing on it, the current system privileges spell-out. Chomsky's system, on the other hand, privileges SCM. Many have, however, argued that SCM takes place so that the moving element escapes being sent to spell-out, see e.g. Bošković (2007), Fox \& Pesetsky (2005), Stjepanović \& Takahashi (2001); the intuition is in fact present even in Chomsky's analysis (furthermore, no one has ever argued that spell-out depends on SCM in this manner). This in itself argues for a system where spell-out is privileged, i.e. for a system like the one argued for here where spellout is defined on phases, but SCM is not. Furthermore, the current system does not need anything like the PIC, which is needed in Chomsky's system. All we have is the assumption that phases are sent to spell-out, with SCM taking place so that the moving element avoids being sent to spell-out. ${ }^{32}$

ment via SpecCP, like Afrikaans (i), where the preposition was assumed to be stranded in the intermediate SpecCP during successive cyclic movement, the embedded verb being located in C (see Du Plessis 1977), they have also been shown not to provide evidence for such movement (see Den Dikken 2009a,b and references therein). Thus, the fact that in (ii), where dink does not move to $\mathrm{C}$, the stranded preposition must precede, not follow, the verb shows that the preposition is not stranded in SpecCP, but in a position above it in the higher clause (which fits the current analysis); see den Dikken (2009a), Den Besten (2010), and Rackowski and Richards (2005) for additional evidence against the-stranding-P-in-SpecCP analysis of (i).

(i) waar/wat dink julle voor werk ons? where/what think you.PL for work we

(ii) eksou graag wou weet waar julle<voor $>$ dink $<*$ voor $>$ dat ons werk. I would gladly wanted know where you for think for that we work 'I would like to know what you think we work for.' $\quad$ (Den Dikken 2009a:100)

31 Recall, however, that under Chomsky's analysis spell-out does target phases with matrix clauses. Under the current analysis, spell-out is consistent in that it always targets only phases.

32 The analysis thus most naturally fits with systems where the driving force for successive-cyclic movement is implemented in this way, as in e.g. Bošković (2007). 
At any rate, what is important for our purposes is that phase $\mathrm{X}$ is completely inaccessible when the next phasal head is merged. Movement from X is then possible only if $X$ is first merged with a non-phasal head, which can "pull" the moving element out of $\mathrm{X}$ before the next phasal head enters the structure. Wh can then move out of $\mathrm{CP}$ in (77) only in the absence of Y.

(77) $\mathbf{H ~ L ~ ( Y ) ~}\left[_{\mathrm{CP}} \mathbf{C}\left[\left[_{\mathrm{IP}}\right.\right.\right.$ wh $\left.]\right]$

Extraction is thus banned in phase-over-phase configurations, which deduces (67).

An important point is in order. While extraction is disallowed from phases that function as phasal complements, such phases themselves can move (unless independent factors interfere, as with the movement of a $\mathrm{CP}$ complement of $\mathrm{N}$ ). This also quite naturally falls out from the current analysis, which dispenses wih the PIC. The conception of spell-out adopted here is essentially Uriagereka's (1999) original conception of spellout, which also does not have the PIC. Crucially, Uriagereka argues that when a phrase is sent to spell-out, nothing within it is available for further syntactic operations but the phrase itself is available. In his terms, sending A to spell-out, which results in establishing word order within A, turns A essentially into a compound/lexical item whose internal structure is inaccessible to the syntax. A itself is, however, accessible. As a result, while movement from the nominal complement in (40) is disallowed (we are dealing here with a phase that functions as a phasal complement), movement of the complement itself, as in (39), is allowed. When $\mathrm{N}$ merges with its complement, it triggers its spell-out. Nothing within the complement is then accessible for movement. However, the complement itself is accessible. Thus, in (78), the structure of (39)-(40) (I adopt the standard assumption that there is more than one phrase in the NP-functional domain), merger of $\mathrm{N}$ with $\mathrm{K}$ triggers spell-out of $\mathrm{K}$. $\mathrm{K}$ is still accessible to $\mathrm{X}$, a non-phasal head (though nothing within $\mathrm{K}$ is), hence $\mathrm{K}$ can move to SpecXP. Merger of D triggers spellout of NP; however, this does not matter since K has already moved outside of NP.

\section{(78) $\left[_{\mathrm{DP}}\left[\left[_{\mathrm{XP}} \mathrm{X}\left[_{\mathrm{NP}} \mathrm{N}\right.\right.\right.\right.$ K] $\left.]\right]$}

\subsection{Stress assignment in English: the Bresnan/Legate argument for multiple spell-out}

Now that the details of the current approach to successive-cyclic movement and spellout, where spell-out targets phases and successive-cyclic movement targets non-phasal projections above phases, have been laid down I return to stress assignment. In particular, we will see in this section that Legate's (2003) discussion of primary stress assignment in English provides evidence for the current approach to successive-cyclic movement and spell-out.

Consider (79)-(81), where the relevant word bearing primary stress is underlined.

(79) a. Mary fixed the bike.

b. Mary fixed it.

(Legate 2003:511) 
(80) a. Mary liked the proposal that George leave.

b. Mary liked the proposal that George left.

(Bresnan 1972:75)

(81) a. Please put away the dishes.

b. ?Please put the dishes away.

(Legate 2003:512)

Since the discussion in this section is based on a generalization regarding primary stress assignment reached in Legate (2003), I will couch it within the approach to stress assignment in English adopted by Legate. Legate assumes the Nuclear Stress Rule (NSR), where the primary stress in English is assigned to the final stress bearing element in the VP (i.e. the rightmost element), hence the contrast in (79). ${ }^{33}$ The NSR is also responsible for stress assignment in (80a). As for (80b), the example represents one of the original arguments for multiple spell-out. In particular, based on such examples, Bresnan (1972) argues the NSR applies cyclically: in (80b), it applies before proposal moves from the most embedded object position (see Vergnaud 1974; Kayne 1994), assigning stress to proposal (in the current theory, this would be handled in terms of multiple spell-out). In (81a), the NSR applies normally, assigning stress to dishes. Importantly, in (81b), which is generally assumed to involve movement of the dishes, in particular, object shift (see Johnson 1991; Lasnik 1999, 2001; Gallego and Uriagereka 2007), the NSR can assign stress to away. Apparently, in (80b) the NSR applies before the object undergoes movement, assigning stress to it, but in (81b) the NSR applies after the object undergoes movement, hence it does not assign stress to it. The question is how this difference regarding stress assignment in (80b) and (81b) can be captured. As noted above, the dishes in (81b) is generally assumed to undergo object shift, moving to SpecvP. Under the standard analysis, where $\mathrm{vP}$ is a phase and successive-cyclic movement targets phasal edges, the object in (80b) also moves to SpecvP. After this movement, the VP complement of $\mathrm{v}$ is sent to spell-out in both (80b) and (81b). (80b) and (81b) then have the same derivation in all relevant respects (see (82), which gives the relevant part of the structure (recall $\mathrm{t}_{\mathrm{i}}$ is sentence final, hence the dishes/proposal is in the position to be assigned stress by the NSR prior to the movement)). It is difficult to differentiate (80b) and (81b) with respect to stress assignment under this analysis, which relies on the standard assumptions regarding phases, successive-cyclic movement, and spell-out.

(82) $\left[_{\mathrm{vP}}\right.$ the dishes/proposal $\left.{ }_{\mathrm{i}}\left[\mathrm{vP} \ldots \mathrm{t}_{\mathrm{i}}\right]\right]$

33 Kratzer and Selkirk (2007) do not appeal to the NSR in their analysis of German (see section 4). There is a good deal of discussion in the literature regarding whether the NSR applies in German, and if so, in which way (to capture the relevant differences between German and English), see e.g. Zubizarreta (1998) (there are conflicting data claims in Kratzer and Selkirk 2007 and Zubizarreta 1998 however). Since determining the precise implementation of the stress assigning mechanism (and capturing crosslinguistic variation in this domain) is beyond the scope of this article, I simply use the mechanisms the works cited here rely on (for a multiple spell-out approach to the NSR, see also Adger 2007). 
How can the contrast between (80b) and (81b) then be accounted for? Interestingly, Legate (2003) proposes an account which is inconsistent with the standard assumptions regarding successive-cyclic movement and spell-out, discussed above regarding (82), but fits perfectly with the current approach. Legate argues that the crucial difference between (80b) and (81b) is that object movement in (80b) takes place to a position outside of the lowest spell-out domain, while in (81b) the object moves to a position within the lowest spell-out domain; in other words, she argues that there is only one copy of the object in the input to PF in the first phase of (80b), while there are two copies of the object in the input to PF in the first phase of (81b). As a result, when the PF operation that deletes non-initial copies within a spell-out domain applies in (81b), it deletes the lower copy of the object. The NSR then assigns stress to away, the rightmost element within the spell-out unit. Turning to (80b), since there is only one copy of the object in the first spell-out domain of this construction, the PF deletion operation that deletes non-initial copies, which treats each phase as a separate unit, does not delete this element when it applies to the first spell-out domain. The NSR then applies, assigning stress to proposal, as the rightmost element within this spell-out domain. ${ }^{34}$

At any rate, putting the details of the implementation aside, what's important here is Legate's proposal that what differentiates (80b) and (81b) is that the object in (80b) moves outside of the lowest spell-out domain, while in (81b) it moves within it, as a result of which there is only one copy of the object in the first spell-out domain of (80b), while there are two such copies in the first spell-out domain of (81b). This is in fact exactly what happens on the current analysis. As discussed above, the dishes undergoes object shift to SpecvP in (81b), with vP being a phase. However, object movement in (80b) does not target the same position. In contrast to the standard analysis, where successive-cyclic movement targets phasal edges, in the current analysis successive-cyclic movement targets phrases above phases. The object in (80b) then does not move to SpecvP, but to the Spec of the first phrase above vP. ${ }^{35}$ This gives us (83)-(84) for (80b) and (81b) respectively.

(83) $\left[_{\mathrm{XP}}\right.$ the proposal $\left.{ }_{\mathrm{i}}\left[{ }_{\mathrm{VP}}\left[\mathrm{VP}, \ldots \mathrm{t}_{\mathrm{i}}\right]\right]\right]$

(84) $\left[_{\mathrm{vP}}\right.$ the dishes $\left.{ }_{\mathrm{i}}\left[\mathrm{vP} \ldots \mathrm{t}_{\mathrm{i}}\right]\right]$

(80b) and (81b) thus have very different derivations when it comes to object movement in the current analysis. Most importantly, the derivations of (80b) and (81b) in

34 At a later phasal/spell-out domain, this occurrence of proposal is deleted in favor of a higher occurrence, with the primary stress realized on this higher occurrence (i.e. the occurrence that is not deleted; see Legate 2003 for details).

35 Since the identity of this phrase is not important for our purposes, I simply use XP. Note that analyses that assume that at least in some cases English has object shift also assume that $\mathrm{V}$ in English moves, though not as high as in Romance. The implicit assumption here is that there is more than one phrase above $\mathrm{vP}$ in the inflectional domain; there is in fact a great deal of evidence that simple TP-over-vP structure is inadequate, see e.g. Belletti (1990), Stjepanović (1998), Cinque (1999), Bošković (2001) (regarding V-movement), Bobaljik and Jonas (1996) (regarding subject positions) and Bošković (2004) (regarding floating quantifiers). 
the current system fit perfectly Legate's account of the contrast between (80b) and (81b) regarding stress assignment. Recall Legate crucially argues that the object in (80b) moves to a position outside of the first spell-out domain, while the object in (81b) moves to a position within the first spell-out domain, as a result of which there is only one copy of the object in the first spell-out domain of (80b) while there are two such copies in the first spell-out domain of $(81 b)$. This is exactly what happens under the current analysis. Given that spell-out targets phases, what is sent to spell-out in both (83) and (84) is vP. The object then moves outside of the first spell-out domain in (80b)/ (83) but not in (81b)/(84). The stress assignment facts discussed by Legate (2003) can then be interpreted as providing additional evidence for the approach to spell-out and successive-cyclic movement argued for here.

\subsection{CED effects}

Before concluding, I will briefly discuss some consequences of the analysis from section 5.2., which crucially relies on phasal spell-out, for the locality of movement.

In addition to deducing the Phase-over-Phase constraint from (67), turning it into a theorem, the analysis also captures the traditional ban on extraction from subjects in SpecIP. Consider (85).

(85) $\left[_{\mathrm{CP}}\left[{ }_{\mathrm{IP}}\right.\right.$ Subject $[$, $\left.\left.]\right]\right]$

Recall that a phase is completely inaccessible to the higher phase head. Since subjects are phases (possibly only DPs), the subject is inaccessible to $\mathrm{C}$, the next phasal head, hence $\mathrm{C}$ cannot attract anything out of it. (85) does not literally involve a phaseover-phase configuration. IP, a non-phase, dominates the subject but not CP. However, this is not enough. What is needed is for a non-phasal head to intervene between the two phases, i.e. for a non-phasal head to c-command the lower phase so that it can probe into it, attracting the moving element out of it. Since I does not c-command the subject, it cannot attract anything out of it. Extraction from subjects in SpecIP is then banned. ${ }^{36}$

The analysis extends to the ban on extraction from adjuncts if adjuncts are adjoined to complements of phasal heads (VP and IP). Consider (86), where $\mathrm{K}$ is also a phase (CP, DP, or PP).

$\left.\left.\left.(86)_{\mathrm{VP}}\right] \mathrm{K}_{\mathrm{VP}}\right]_{\mathrm{vP}}\right]$

The only element that intervenes between the vP phase (which sends $\mathrm{K}$ to spellout) and $\mathrm{K}$ is a VP-segment, which is irrelevant (V cannot attract anything out of $\mathrm{K}$ since $\mathrm{V}$ does not c-command $\mathrm{K}$ ). Extraction from $\mathrm{K}$ is then impossible. The analysis

36 Subjects in SpecvP allow extraction (Stepanov 2007). Here, at least one non-phasal head intervenes between $\mathrm{vP}$ and $\mathrm{CP}$, which can pull out a moving element from the subject before $\mathrm{C}$ is merged (note that since only merger of a phasal head (not a projection of a phasal head) triggers spell-out, subject in SpecvP is not sent to spell-out until C is merged). 
thus captures the ban on extraction from adjuncts. ${ }^{37}$ In fact, the ban on extraction from subjects and the ban on extraction from adjuncts are unified with the Complex XP Constraint, all three being reduced to the ban on extraction in phase-over-phase contexts. (67) should, however, be slightly revised in light of the above discussion.

(87) The Phase-over-Phase Theorem: Extraction is banned from a phase that is immediately c-commanded by a phasal head (where $X$ is immediately c-commanded by head $\mathrm{Y}$ if there is no head $\mathrm{Z}$ such that $\mathrm{Z}$ c-commands $\mathrm{X}$ but not $\mathrm{Y}$ ).

\subsection{Phase collapsing}

Consider now why P-stranding does not matter in the contrast in (37)/(35) vs (38)/(36), i.e. why (37) (repeated as (88)) does not instantiate (47). Many have implemented the reanalysis approach to P-stranding in terms of P-incorporation (overt or covert). (37)/ (88) then involves P-to-N movement.

$$
\text { Who } o_{i} \text { did you see }\left[{ }_{\mathrm{DP}}\left[{ }_{\mathrm{XP}} t_{i}\left[{ }_{\mathrm{NP}} \text { friends of }\left[_{\mathrm{PP}} t_{j} t_{i}\right]\right]\right]\right] \text { ? }
$$

Based on a number of cases, some of which are discussed below, Bošković (2015a) proposes phase collapsing for phasal projections headed by two phase heads (due to the movement of the lower phase head to the higher phase head): the two phases are collapsed into one, the lower phrase not being a phase. ${ }^{38} \mathrm{PP}$ is then not sent to spell-out in (88) (note that there is a feature on the $\mathrm{P}$ and $\mathrm{N}$ that drives the movement in question which also indicates that the phasehood of PP will be voided hence PP is not spelledout when $\mathrm{N}$ is merged). As a result, when $\mathrm{X}$ enters the structure who can move out of NP. XP not being a phase, who is available for movement after D is merged. ${ }^{39}$

Note that (89) is still ruled out: merger of of' causes spell-out of DP; who is then stuck within it.

(89) *Who did you see enemies $\left[{ }_{\mathrm{PP}}\right.$, of ${ }^{\prime}\left[_{\mathrm{DP}}\left[{ }_{\mathrm{XP}} t_{i}\left[{ }_{\mathrm{NP}}\right.\right.\right.$ friends of $\left.\left.\left.\left.{ }_{\mathrm{j}}\left[_{\mathrm{PP}}, t_{j} t_{i}\right]\right]\right]\right]\right]$ ?

$O f^{\prime}$ behaves like a phase head at the point of merger, sending DP to spell-out. The reason for this may be that the noun that can void its phasehood (enemies) has not yet

37 Adjuncts in ergative constructions require additional assumptions which I cannot go into here due to space limitations.

38 While there is similarity between phase collapsing and phase sliding/extension (den Dikken 2007; Gallego and Uriagereka 2007), where head movement extends the phase to the next projection, the former is much more constrained - it arises only when a phasal head moves to a phasal head, hence it also cannot turn a non-phase into a phase (see Bošković 2015a for a comparison; Bošković 2015a also assumes that the moved phase head must be a sister to a segment of the higher phase head in the phase-collapsing configuration).

39 Note also that (88) is another case that teases apart (67) and (63) - it conforms with (67) but not (63). ((88) involves extraction out of the complement of a lexical head but not a phase-over-phase configuration, PP not being a phase.) 
entered the structure (this doesn't affect (88)) or that P-incorporation in English occurs only under P-stranding, hence not for of' in (89). There is reason to favor the latter analysis, where the phasehood of PP' is never voided.

Setswana, a Bantu language where the noun precedes all other DP elements, which is analyzed in terms of N-to-D movement (see Carstens 2010), does not display CNPC effects.

(90) Ke m-angyo o utlw-ile-ng ma-gatwe a gorentša e lom-ile? it C1-who C1Rel 2sgSM hear-perf-Rel C6-rumor C6SM that C9-dog C9SM bite-perf 'Who did you hear rumors that a dog bit?'

(Bošković 2015a:651)

This follows from phase collapsing. Due to N-to-D, the matrix object is headed by two phase heads, D and N. (I assume XP is either not present in Setswana or it is present, with $\mathrm{X}$ moving to $\mathrm{D}$ and $\mathrm{N}$ to the $\mathrm{X}+\mathrm{D}$ head.) Due to phase collapsing, NP is then not a phase. Crucially, $\mathrm{N}$ doesn't cause spell-out of $\mathrm{CP}$, hence extraction from $\mathrm{CP}$ is possible. This means that already at the point of merger, $\mathrm{N}$ is treated as a non-phasal head. (The presence of a $\mathrm{D}$ feature on $\mathrm{N}$, which drives N-to-D, is sufficient to determine locally that the phasehood of $\mathrm{N}$ will be voided.) The implication of this for (89) is that of' in (89) does not incorporate; P-incorporation in English occurs only in P-stranding contexts, hence of' is a phasal head in (89) (the alternative account of (89) noted above cannot capture (90)). Returning to (90), since the first phase above CP is DP, the CP is not sent to spell-out until D is merged. Since there is at least one non-phasal projection between CP and DP (NP and possibly XP), 'who' can move out of the CP phase before $\mathrm{D}$ enters the structure, triggering spell-out of the $\mathrm{CP}$.

Recall now the deduction of the ban on extraction from adjuncts. The first head above KP in (91) is v, which is also a phasal head hence cannot attract anything from $\mathrm{KP}$ (since it triggers immediate spell-out of KP). The account makes a prediction. If $\mathrm{K}$ moves to v, KP phasehood will be voided due to phase collapsing. KP will then not be spelled-out until $\mathrm{C}$ is merged (triggering spell-out for the whole $\mathrm{vP}$ phase). Movement from KP should then be possible since there are several heads lower than $\mathrm{C}$ that can pull the moving element out of $\mathrm{KP}$ before $\mathrm{C}$ is merged.

(91) $\left.\left.\left[\mathrm{vP}_{\mathrm{VP}}\right] \mathrm{KP}_{\mathrm{VP}}\right]_{\mathrm{vP}}\right]$

The surprising prediction is borne out. Galician has a phenomenon of D-incorporation, which voids islandhood, as discussed in Uriagereka (1988) and Bošković (2013b). Extraction from adjuncts is banned in Galician, as in (92). However, the ban is voided with D-incorporation, exactly as expected under the current analysis (I assume D incorporates into $\mathrm{V}+\mathrm{v}){ }^{40}$

40 D-incorporation does not rescue CNPC violations in Galician (see Bošković 2015a). This is expected: what is responsible for the CNPC effect is the phasehood of NP, which is not affected by D-incorporation. 


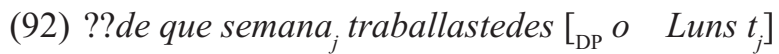

of which week worked the Monday

'Of which week did you guys work the Monday?'

(93) de que semana ${ }_{j}$ traballastede-lo ${ }_{i}\left[{ }_{\mathrm{DP}}\left[{ }_{\mathrm{D}}, t_{i}\right.\right.$ Luns $\left.\left.t_{j}\right]\right]$

\section{CONCLUSION}

The article has argued that what is sent to spell-out is phases, not phasal complements. Phasal spell-out has obvious theoretical advantages over phasal complement spell-out. In contrast to phases, phasal complements have no theoretical status. Furthermore, the phasal complement spell-out approach still requires phasal spell-out in one context (matrix clauses), while on the phasal spell-out approach only phases are ever sent to spell-out. We have also seen that the PIC can be eliminated under phasal spell-out. Phasal spell-out also fits more naturally with the recent labeling system, where labeling is interface-driven and what is being labeled is phases, not phasal complements.

Several empirical arguments have also been presented in favor of phasal spell-out regarding syntax-phonology interaction, the relevant phenomena being cliticization in Bulgarian and Arabic, stress assignment in German and English, raddoppiamento fonosintattico in Abruzzese, and tone sandhi in Taiwanese. These phenomena were shown to illustrate the impossibility of PF interaction between the edge of phase XP and material outside of phase XP, as well as the possibility of PF interaction between the edge of phase XP and the complement of X, both of which are expected under phasal spell-out, but not under phasal complement spell-out. The standard assumption that $\mathrm{CP}$ corresponds to an intonational phrase boundary also fits more naturally with phasal spell-out.

Another argument concerned the Phase-over-Phase constraint, a broad generalization that covers a number of islands. Taking as the point of departure the Complex NP Constraint, we have seen that extraction is banned not only from clausal but all complements of nouns. Adjectives, prepositions, and ergative verbs pattern with nouns in this respect, extraction from the complement of a lexical head being possible only with non-ergative verbs. Adopting an approach to phases where the highest projection in the thematic domain of a lexical head functions as a phase, the ban on extraction from complements of lexical heads was recast as the ban on extraction in double-phase configurations, i.e. the ban on extraction from phases that are immediately c-commanded by a phasal head - the Phase-over-Phase Constraint. The constraint was also extended to the CED, i.e. the ban on extraction from subjects and adjuncts, unifying all of these under the ban on extraction in phase-over-phase configurations. A deduction of the Phase-over-Phase constraint was given where phase XP is completely inaccessible, with no edge/PIC exception, once a higher phase head enters the structure. The crucial component of the analysis was phasal spell-out, i.e. that what is sent to spell-out is phases, not phasal complements. As a result, nothing within phase XP is accessible to higher phase YP, given that merger of Y leads to immediate spell-out of XP. Since phase XP is completely inaccessible when the next phasal head is merged, movement 
from it is possible only if XP is first merged with a non-phasal head, which can pull the moving element out of XP before the next phasal head is merged. In Complex XP Constraint and CED contexts, the first merged head is a phasal head - we are dealing here with phase-over-phase configurations, which disallow extraction.

An interesting consequence of this system is that while what is sent to spell-out is full phases, what is targeted by successive-cyclic movement is not phases, but phrases above phases. Phases are relevant to many phenomena. There is, however, a problem with spell-out and successive-cyclic movement in this respect. Assuming that what is sent to spell-out is no longer accessible to the syntax, it is not possible to state the domain for both spell-out and successive-cyclic movement in terms of phases. If successive-cyclic movement were to target spell-out units, the moving element would also be sent to spell-out hence would be frozen for any further movement. Only one of the mechanisms in question can then be stated in terms of phases. We have here the following situation: YP is sent to spell-out and movement targets $\mathrm{XP}$ right above it, and either YP or XP is a phase (with movement to XP taking place after YP is spelled out). Chomsky (2001) takes XP to be the phase while the current system takes YP to be the phase. As noted above, in addition to deducing the Phaseover-Phase Constraint, the current system allows us to dispense with the PIC. All we have is the assumption that phases are sent to spell-out, with successive-cyclic movement taking place so that the moving element avoids being sent to spell-out. To the extent that it is successful the analysis of successive-cyclic movement presented here thus provides another argument for phasal spell-out, a different kind of argument from those involving syntax-phonology interaction. The argument was also confirmed by certain facts concerning stress assignment.

\section{References}

ABELS, Klaus (2001) “The Predicate Cleft Construction in Russian.” In: S. Franks/T. Holloway King/M. Yadroff (eds), Formal Approaches to Slavic Linguistics: The Indiana Meeting 2000. Ann Arbor: Michigan Slavic Publications, 1-19.

ABELS, Klaus (2003) Successive cyclicity, anti-locality, and adposition stranding. Doctoral dissertation, University of Connecticut.

ADGER, David (2007) "Stress and phasal syntax." Linguistic Analysis 33, 238-266.

AGBAYANI, Brian (2000) "Wh-subjects in English and the vacuous movement hypothesis." Linguistic Inquiry 31, 703-713.

ALBUHAYRI, Salem. 2013. The pronominal system in Standard Arabic: Strong, clitic and affixal pronouns. MA Thesis. Arizona State University.

AN, Duk-Ho (2007) Syntax at the PF interface. Doctoral dissertation. University of Connecticut.

BACH, Emmon/George HORN (1976) "Remarks on 'Conditions on Transformations'." Linguistic Inquiry 7, 265-299.

BENMAMOUN, Elabbas (2000) The feature structure of functional categories: A comparative study of Arabic Dialects. Oxford: Oxford University Press. 
BESTEN, Hans den (2010) "Is there"preposition stranding in Comp"in Afrikaans? No way!" In: C. J.-W. Zwart/M. de Vries (eds), Structure preserved: Studies in syntax for Jan Koster. Amsterdam: John Benjamins, 57-64.

BELLETTI, Adriana (1990) Generalized verb movement. Turin: Rosenberg and Sellier. BELLETTI, Adriana/Luigi RIZZI (1988) "Psych-verbs and theta theory." Natural Language and Linguistic Theory 6, 291-352.

BIBERAUER, Theresa/Roberta D'ALESSANDRO (2006) "Syntactic doubling and the encoding of voice in Eastern Abruzzese." In: D. Baumer/D. Montero/M. Scanlon (eds), Proceedings of WCCFL 25. Somerville, M: Cascadilla Press, 87-95.

BOBALJIK, Jonathan (2002) "A-Chains at the PF-interface: Copies and 'covert' movement." Natural Language and Linguistic Theory 20.2, 197-267.

BOBALJIK, Jonathan/Dianne JONAS (1996) "Subject positions and the roles of TP." Linguistic Inquiry 27, 195-236.

BOECKX, Cedric (2003) Islands and Chains. Amsterdam: John Benjamins.

BOECKX, Cedric (2004) Bare syntax. Ms., Harvard University.

BOŠKOVIĆ, Željko (1994) "D-structure, theta-criterion, and movement into thetapositions." Linguistic Analysis 24, 247-286.

BOŠKOVIĆ, Željko (2001) On the nature of the syntax-phonology interface: Cliticization and related phenomena. Amsterdam: Elsevier Science.

BOŠKOVIĆ, Željko (2002a) "On multiple wh-fronting." Linguistic Inquiry 33, 351-383.

BOŠKOVIĆ, Željko (2002b) "Clitics as non-branching elements and the Linear Correspondence Axiom.” Linguistic Inquiry 33, 329-340.

BOŠKOVIĆ, Željko (2004) "Be careful where you float your quantifiers." Natural Language and Linguistic Theory 22, 681-742.

BOŠKOVIĆ, Željko (2007) "On the locality and motivation of Move and Agree: An even more minimal theory." Linguistic Inquiry 38, 589-644.

BOŠKOVIĆ, Željko (2008) "On successive cyclic movement and the freezing effect of feature checking." In: J. M. Hartmann/V. Hegedüs/H. van Riemsdijk (eds), Sounds of silence: Empty elements in syntax and phonology. Amsterdam: Elsevier North Holland, 195-233.

BOŠKOVIĆ, Željko (2012) “On NPs and clauses.” In: G. Grewendorf/T. E. Zimmermann (eds), Discourse and grammar: From sentence types to lexical categories. Berlin: de Gruyter, 179-242.

BOŠKOVIĆ, Željko (2013a) "Phases beyond clauses." In: L. Schürcks/A. Giannakidou/U. Etxeberria (eds), The nominal structure in Slavic and beyond. Berlin: de Gruyter, 75-128.

BOŠKOVIĆ, Željko (2013b) "Traces do not head islands: What can PF deletion rescue?" In: Y. Miyamoto et al (eds), Deep Insights, Broad Perspectives: Essays in Honor of Mamoru Saito. Tokyo: Kaitakusha, 56-93.

BOŠKOVIĆ, Željko (2014) "Now I'm a phase, now I'm not a phase." Linguistic Inquiry 45, 27-89. 
BOŠKOVIĆ, Željko (2015a) "From the Complex NP Constraint to everything: On deep extractions across categories." The Linguistic Review 32, 603-669.

BOŠKOVIĆ, Željko (2015b) "Deducing the Generalized XP Constraint from phasal spell-out." In: M. Ziková/P. Caha/M. Dočekal (eds), Slavic Languages in the Perspective of Formal Grammar: Proceedings of FDSL 10.5, Brno 2014. Bern: Peter Lang, 79-100.

BOŠKOVIĆ, Željko (2016a) "Contextual phasehood and the ban on extraction from complements of lexical heads: When does X become a phase?" In: M. Yasui/M. Mizuguchi (eds), Phase theory and its consequences. Tokyo: Kaitakusha, 5-39.

BOŠKOVIĆ, Željko (2016b) "On the timing of labeling: Deducing Comp-trace effects, the Subject Condition, the Adjunct Condition, and tucking in from labeling." The Linguistic Review 33, 17-66.

BOŠKOVIĆ, Željko (2016c) Tone sandhi in Taiwanese and phasal spell-out. Ms., University of Connecticut.

BOŠKOVIĆ, Željko/Howard LASNIK (2003) "On the distribution of null complementizers." Linguistic Inquiry 34, 527-546.

BOŠKOVIĆ, Željko/Jairo NUNES (2007) "The copy theory of movement: A view from PF." In: N. Corver/J. Nunes (eds), The copy theory of movement. Amsterdam: Benjamins, 13-74.

BRESNAN, Joan (1972) Theory of complementation in English syntax. Doctoral dissertation, MIT.

CARSTENS, Vicki (2010) Head-movement in Bantu DPs. Presented at NELS 41, University of Pennsylvania.

CHENG, Lisa/Laura DOWNING (2016) "Phasal Syntax=Cyclic Phonology?" Syntax 19, 156-191.

CHOMSKY, Noam (1973) "Conditions on transformations." In: S. Anderson/P. Kiparsky (eds), A festschrift for Morris Halle. New York: Holt, Rinehart and Winston, 232-286.

CHOMSKY, Noam (1986) Barriers. Cambridge: MIT Press.

CHOMSKY, Noam (1993) "A minimalist program for linguistic theory.” In: K. Hale/ S. J. Keyser (eds), The view from Building 20. Cambridge: MIT Press, 1-52.

CHOMSKY, Noam (2000) "Minimalist inquiries." In: R. Martin/D. Michaels/J. Uriagereka (eds), Step by step: Essays on minimalist syntax in honor of Howard Lasnik.Cambridge: MIT Press, 89-155.

CHOMSKY, Noam. 2001. "Derivation by phase.” In: M. Kenstowicz (ed.), Ken Hale: A life in language. Cambridge: MIT Press, 1-52.

CHOMSKY, Noam (2013) "Problems of projection." Lingua 130, 33-49.

CHOMSKY, Noam (2015) "Problems of projection: Extensions." In: E. Di Domenico/C. Hamann/S. Matteini (eds), Structures, Strategies and Beyond: Studies in Honour of Adriana Belletti. Amsterdam: John Benjamins, 3-16.

COLLINS, Chris (2002) "Eliminating labels.” In: S. D. Epstein/T. D. Seely (eds), Derivation and explanation in minimalist syntax. New York: Wiley, 42-64. 
CINQUE, Guglielmo (1999) Adverbs and functional heads: A cross-linguistic perspective. Oxford: Oxford University Press.

D'ALESSANDRO, Roberta/Tobias SCHEER (2015) "Modular PIC." Linguistic Inquiry 46, 593-624.

D'ALESSANDRO, Roberta/Ian ROBERTS (2010) "Past participle agreement in Abruzzese: Split auxiliary selection and the null-subject parameter." Natural Language and Linguistic Theory 28, 41-72.

DIKKEN, Marcel den (2007) "Phase extension: Contours of a theory of the role of head movement in phrasal extraction." Theoretical Linguistics 33, 1-41.

DIKKEN, Marcel den (2009a) "Arguments for successive-cyclic movement through SpecCP." Linguistic Variation Yearbook 9, 89-126.

DIKKEN, Marcel den (2009b) "On the nature and distribution of successive cyclicity. Adjunction, resumption, and scope marking as the roads to success in long-distance relation building." Ms., CUNY Graduate Center, New York.

DIESING, Molly (1992) Indefinites. Cambridge, MA: MIT Press.

DIESING, Molly (1996) "Semantic variables and object shift." In: H. Thráinsson/S. Epstein/S. Peter (eds), Studies in comparative Germanic syntax. Dordrecht: Kluwer. 66-84.

EPSTEIN, Samuel David (1999) "Un-principled syntax: The derivation of syntactic relations.” In: S. Epstein/N. Hornstein (eds), Working minimalism. Cambridge: MIT Press. 317-345.

EPSTEIN, Samuel David/Erich GROAT/Ruriko KAWASHIMA/Hisatsugu KITAHARA (1998) A derivational approach to syntactic relations. New York: Oxford University Press.

FASSI FEHRI, Abdelkader (1988) "Agreement in Arabic, binding and coherence." In: M. Barlow/C. Ferguson (eds), Agreement in natural language. Stanford: CSLI, 107-158.

FASSI FEHRI, Abdelkader (1993) Issues in the structure of Arabic clauses and words. Dordrecht: Kluwer.

FOX, Danny (1998) Economy and semantic interpretation. Doctoral dissertation, MIT.

FOX, Danny/David PESETSKY (2005) "Cyclic linearization of syntactic structure." Theoretical Linguistics 31, 1-46.

FINER, Daniel (2003) "Phases and movement in Selayarese." In: A. Rackowski/N. Richards (eds), Proceedings of AFLA 8. Department of Linguistics and Philosophy, MIT, 157-69.

FRANKS, Steven (1994) "Parametric properties of numeral phrases in Slavic." Natural Language and Linguistic Theory 12, 570-649.

FRANKS, Steven (1998) Clitics in Slavic. Paper presented at the Comparative Slavic Morphosyntax Workshop, Spencer Creek, Indiana, June 1998.

FRANKS, Steven/Željko BOŠKOVIĆ (2001) "An argument for multiple spell-out." Linguistic Inquiry 32, 174-183. 
FRANKS, Steven/Tracy KING (2000) A handbook of Slavic clitics. Oxford: Oxford University Press.

GALLEGO, Ángel/Juan URIAGEREKA (2007) “Conditions on sub-extraction.” In: L. Eguren/O. Fernández-Soriano (eds). Coreference, modality, and focus. Amsterdam: John Benjamins, 45-70.

GRIMSHAW, Jane (1990) Argument structure. Cambridge: MIT Press.

GROHMANN, Kleanthes (2003) Prolific domains. Amsterdam: John Benjamins.

HOLES, Clive (2004) Modern Arabic structures, functions and varieties. Georgetown University Press: Washington DC.

HORROCKS, Geoffrey/Melita STAVROU (1987) "Bounding theory and Greek syntax." Journal of Linguistics 23, 79-108.

ISHIHARA, Shinichiro (2007) "Major phrase, focus intonation, multiple spell-out (MaP, FI, MSO)." The Linguistic Review 24, 137-167.

JOHNSON, Kyle (1991) “Object positions." Natural Language and Linguistic Theory 9, 577-636.

JOHNSON, Kyle (1992) "Scope and binding theory." Syntax and Semantics 26, 259-275.

KAHNEMUYIPOUR, Arsalan (2003) "Syntactic categories and Persian stress." Natural Language and Linguistic Theory 12, 333-379.

KAYNE, Richard (1994) The antisymmetry of syntax. Cambridge: MIT Press.

KHALAILY, Samir (1995) "On the relevance of the split complementizer hypothesis." In: R. Eckhardt/V. van Geenhoven (eds), Proceedings of ConSole II. The Hague: Holland Academic Graphics, 95-111.

KRATZER, Angelika/Elisabeth SELKIRK (2007) "Phase theory and prosodic spellout: The case of verbs." The Linguistic Review 24, 93-135.

LAMBOVA, Mariana (2002) "On A'-movements in Bulgarian and their interaction." The Linguistic Review 18, 327-374.

LAHNE, Antje (2008) Where there is fire there is smoke: Local modelling of successive-cyclic movement. Doctoral dissertation. University of Leipzig.

LANDAU, Idan (2003) Modular recoverability: Chain resolution in Hebrew V(P)fronting. Ms., Beer-Sheva, Israel.

LANDAU, Idan (2010) The locative syntax of experiencers. Cambridge: MIT Press.

LASNIK, Howard (1999) Minimalist analysis. Oxford: Blackwell.

LASNIK, Howard (2001) “Subjects, objects, and the EPP.” In: W. D. Davies/S. Dubinsky (eds), Objects and other subjects: Grammatical functions, functional categories, and configurationality. Dordrecht: Kluwer, 103-121.

LEGATE, Julie Anne (2003) "Some interface properties of the phase." Linguistic Inquiry 34, 506-516.

MCCLOSKEY, James (2000) "Quantifier float and wh-movement in an Irish English." Linguistic Inquiry 31, 57-84.

MIYAGAWA, Shigeru (2003) "A-movement scrambling and options without optionality.” In: S. Karimi (ed.), Word order and scrambling. Oxford: Blackwell, 177-200. 
NESPOR, Marina/Irene VOGEL (1986) Prosodic phonology. Dordrecht: Foris.

NOONAN, Máire (1999) "Successive cyclicity phenomena in wh-movement constructions." Proceedings of the West Coast Conference on Formal Linguistics 18. Somerville: Cascadilla Press, 406-419.

NUNES, Jairo (2009) "Dummy prepositions and the licensing of null subjects in Brazilian Portuguese." In: E. O. Aboh et al (eds), Romance languages and linguistic theory. Amsterdam: Benjamins, 243-265.

PESETSKY, David (1995) Zero syntax. Cambridge: MIT Press.

PESETSKY, David (1998) "Some optimality principles of sentence pronunciation." In: P. Barbosa et al (eds), Is the Best Good Enough. Cambridge: MIT Press and MIT WPL, 337-383.

PESETSKY, David/Esther TORREGO (2001) "T-to-C movement: Causes and consequences.” In: M. Kenstowicz (ed.), Ken Hale: A life in language. Cambridge: MIT Press, 355-426.

PLESSIS, Hans du (1977) “Wh-movement in Afrikaans." Linguistic Inquiry 8, 723-726.

RACKOWSKI, Andrea/Norvin RICHARDS (2005) "Phase edge and extraction." Linguistic Inquiry 36, 565-599.

REGLERO, Lara (2007) "Wh-in-situ interrogatives in Spanish.” Probus 19, 267-297.

ROSS, John Robert (1967) Constraints on variables in syntax. Doctoral dissertation, MIT, Cambridge.

SAFIR, Kenneth (1985) Syntactic chains. Cambridge: Cambridge University Press.

SAITO, Mamoru (2009) "Optional A-scrambling." Japanese/Korean Linguistics 16, 44-63.

SAITO, Mamoru/Keiko MURASUGI (1999) "Subject predication within IP and DP." In: K. Johnson/I. Roberts (eds), Beyond principles and parameters: Essays in memory of Osvaldo Jaeggli. Dordrecht: Kluwer, 167-188.

SALIH, Mahmud Husein (1985) Aspects of clause structure in Standard Arabic: A study in relational grammar. Doctoral dissertation. State University of New York at Buffalo.

SAWADA, Tsuyoshi (2015) Pleonastic merger. Doctoral dissertation. University of Connecticut.

SCHNEIDER-ZIOGA, Patricia (2009) "Wh-agreement and bounded and unbounded movement." In: J. Brucart/A. Gavorro/J. Sola (eds), Merging features. Oxford: Oxford University Press, 46-59.

SELKIRK, Elisabeth (1986) Phonology and syntax: The relation between sound and structure. Cambridge: MIT Press.

SHLONSKY, Ur (1994) "Semitic clitics." In: M. Starke (ed.), Geneva Generative Papers 2. Geneva: University of Geneva, 1-11.

SHLONSKY, Ur (1997) Clause structure and word order in Hebrew and Arabic: An essay in comparative Semitic syntax. Oxford: Oxford University Press.

SHLONSKY, Ur (2000) "Remarks on the complementizer layer of Standard Arabic." In: J. Lecarme/J. Lowenstamm/U. Shlonsky (eds), Research on Afroasiatic Grammar. Amsterdam: Benjamins, 325-343. 
SIMPSON, Andrew/Zoe WU (2002) "IP-raising, tone sandhi and the creation of Sfinal particles: Evidence for cyclic Spell-Out." Journal of East Asian Linguistics 11, 67-99.

STEPANOV, Arthur (2007) “The End of CED?" Syntax 10, 80-126.

STJEPANOVIĆ, Sandra (2003) "A word-order paradox resolved by copy deletion at PF." Linguistic Variation Yearbook 3, 139-177.

STJEPANOVIĆ, Sandra/Shoichi TAKAHASHI (2001) Eliminating the Phase Impenetrability Condition. Presented at the workshop Motivating movement, University of Ulster, January 2001.

TALIĆ, Aida (2013) "Extraordinary complement extraction." Studies in Polish Linguistics $8,127-150$.

URIAGEREKA, Juan (1988) On government. Doctoral dissertation. University of Connecticut.

URIAGEREKA, Juan (1999) “Multiple Spell-Out.” In: S. Epstein/N. Hornstein (eds), Working minimalism. Cambridg: MIT Press, 251-282.

VERGNAUD, Jean-Roger (1974) French relative clauses. Doctoral dissertation. MIT, Cambridge, Mass.

WURMBRAND, Susanne (2014) "Tense and aspect in English infinitives." Linguistic Inquiry 45, 403-447.

ZUBIZARRETA, Maria Luisa (1998) Prosody, focus, and word order. Cambridge: MIT Press.

ZWART, C. Jan-Wouter (1993) Dutch syntax: A minimalist approach. Doctoral dissertation. University of Groningen.

\section{Summary}

\section{WHAT IS SENT TO SPELL-OUT IS PHASES, NOT PHASAL COMPLEMENTS}

An appealing property of the phase theory is that it is relevant to many phenomena, i.e. many domain-based mechanisms are stated in terms of phases. However, although phasal complements have no theoretical status in the phase theory (only phases do), they are taken to define spell-out units. This paper argues for an approach where phases define spell-out domains, which means that what is sent to spell-out is the phase itself. Several arguments to this effect are presented regarding syntax-phonology interaction (in particular, encliticization in Bulgarian and Arabic, stress assignment in German and English, raddoppiamento fonosintattico in Abruzzese, and tone sandhi in Taiwanese), as well as more theoretical issues such as labeling. The assumption, however, has significant consequences for successive-cyclic movement. If phases are sent to spell-out and what is sent to spell-out is inaccessible to the syntax, successive-cyclic movement cannot target phases. Under the account argued for here, successive-cyclic movement therefore does not proceed via phases (i.e. phasal edges). As a result, the account also eliminates the PIC.

Keywords: locality of movement, phases, the Phase-Impenetrability Condition, stress assignment, syntax-phonology interface 
Privlačnost teorije faz leži v dejstvu, da je relevantna pri razlagi več pojavov, pri katerih sodelujejo na domenah osnovani mehanizmi. Čeprav fazna dopolnila nimajo posebnega formalnega statusa $\mathrm{v}$ teoriji faz (tega imajo le faze), se uporabljajo kot definicija enote, ki sodeluje pri točki Loči (Spell-Out). V tem članku zagovarjamo pristop, pri katerem so faze tiste, ki definirajo domeno v točki Loči, kar pomeni, da se v točki Loči ločijo faze same in ne njihova dopolnila. V članku je prikazanih več podatkov, ki potrjujejo zagovarjano trditev s področja vmesnika med skladnjo in fonologijo, kot naprimer enklitizacija $\mathrm{v}$ bolgarščini in arabščini, naglas $\mathrm{v}$ nemščini in angleščini, fonosintaktično podvajanje $\mathrm{v}$ abruzzijskem narečju in tonemski sandhi $\mathrm{v}$ tajvanski mandarinščini. Obravnavanih je tudi več sorodnih teoretičnih vprašanj. Predlagana analiza ima pomembne posledice za zaporedno ciklično premikanje. Če se v točki Loči ločijo faze in če je to, kar se loči, nedostopno za nadaljne postopke v izgradnji, potem zaporedni ciklični premiki ne morejo zadevati faz. Zaporedno ciklično premikanje se torej ne odvija po fazah (tj. faznih robovih). Rezultat analize je tudi izločitev načela o nepredirnosti faz.

Ključne besede: lokalnost premika, faze, načelo o nepredirnosti faz, naglas, vmesnik med skladnjo in fonologijo 